\title{
15. Hippopotamidae from the Baynunah Formation
}

Jean-Renaud Boisserie ${ }^{1}$, Faysal Bibi ${ }^{2}$

${ }^{1}$ Centre Français des Études Éthiopiennes, USR 3137 CNRS, Ambassade de France en Éthiopie, P.O. BOX 5554 Addis Ababa, Éthiopie \& Laboratory Paleontology Evolution Paleoecosystems Paleoprimatology (PALEVOPRIM, UMR CNRS 7262), University of Poitiers, France. jean.renaud.boisserie@univ-poitiers.fr

${ }^{2}$ Museum für Naturkunde, Leibniz Institute for Evolution and Biodiversity Science, Invalidenstrasse 43, 10115 Berlin, Germany.

\begin{abstract}
The Baynunah hippopotamid material provides further evidence for the Hippopotamine Event, which marked the spread and increased ecological impact of the Hippopotaminae into wet habitats across Africa and Eurasia at around 8 Ma. The Baynunah Formation hippopotamid belongs to a hippopotamine species distinct from all other contemporary and later species in having a relatively more elongate symphysis, a feature similar to the earlier (and more primitive) Kenyapotamus. A phylogenetic analysis suggests that this hippopotamine is so far the most primitive for which the mandibular morphology is well known. The morphological affinities of the Baynunah species confirm biogeographic links with Africa and indicate no connection between Afro-Arabian and southern Asian hippopotamids at this time, between 8 and 6 Ma.
\end{abstract}

Running head: Hippopotamidae 


\section{Introduction}

The evolutionary history of the Hippopotamidae was marked around $8 \mathrm{Ma}$ by the abrupt appearance in the fossil record of large hippopotamine forms with relatively high and simple molars. This Hippopotamine Event (Boisserie et al. 2011) marks the shift of hippopotamids from large herbivores rare in fossil faunas to megaherbivores very abundant in wet habitats. The Hippopotamine Event was also characterized by a dramatic increase in specific diversity, from a single non-hippopotamine species known across eastern and northern Africa during the early late Miocene (Kenyapotamus coryndonae Pickford, 1983) to almost a dozen hippopotamine forms by the end of the Miocene (Boisserie et al. 2011). The documentation and detailed understanding of the Hippopotamine Event therefore is key to understanding diversification dynamics of large herbivores during the late Miocene, a time when the core elements of modern biomes were being formed.

Some of the earliest hippopotamines that mark the Hippopotamine Event are poorly known. This is the case of the material from the Baynunah Formation, Abu Dhabi, United Arab Emirates (Whybrow and Hill 1999), which was initially described as Hexaprotodon aff. sahabiensis by Gentry (1999), later revised to Archaeopotamus aff. lothagamensis by Boisserie (2005), and recently attributed to a new species, Archaeopotamus qeshta, by Boisserie et al. (2017a). Outstanding questions remain, however, regarding this extinct Arabian hippopotamine's taxonomic status, biogeographic affinities, and its implications for the age of the biochronologically-dated Baynunah fauna (Bibi et al. 2013; this volume-a). The discovery of new specimens since 2002 has prompted the revision of all fossil material belonging to this hippopotamid and the clarification of its taxonomic status. This contribution describes in detail the mandibular and dental morphology of this material, and confirms its attribution to a new species of the genus Archaeopotamus. 


\section{Material and methods}

The material described here was collected between 1982 and 1995 during surveys led by Peter Whybrow and Andrew Hill (Whybrow and Hill 1999), as well as from 2002 onward during surveys led by Andrew Hill, Faysal Bibi, and Mark Beech. This material is curated by the Historic Environment Department at the Abu Dhabi Department of Culture and Tourism (formerly the Tourism and Culture Authority, formerly the Abu Dhabi Authority for Culture and Heritage) in Abu Dhabi city and the Al Ain National Museum, with the exception of a few specimens housed at the Paleontology Department of the Natural History Museum in London.

The Baynunah specimens were compared with direct observations of other Miocene hippopotamids: the middle to late Miocene Kenyapotamus spp. (Boisserie et al. 2010; Tsubamoto et al. 2016; Boisserie et al. 2017b); the new hippopotamine material from Chorora (Suwa et al. 2015; Katoh et al. 2016; Boisserie et al. 2017c); Archaeopotamus spp. from the Nawata Formation at Lothagam, Kenya (Weston 2000; Weston 2003; Boisserie 2005); Hexaprotodon garyam from the Anthracotheriid Unit at Toros-Ménalla, Chad (Boisserie et al. 2005a); and the hippopotamine remains from the Adu-Asa Formation in the Middle Awash Valley (western margin), Ethiopia (Boisserie and Haile-Selassie 2009). All measurements were taken by JRB, unless mentioned otherwise. Other comparisons were conducted using published data, notably for the material from Sahabi, Libya (Hexaprotodon? sahabiensis Gaziry, 1987). All descriptions follow the nomenclature proposed by Boisserie et al. (2010), and open nomenclature follows the recommendations of Bengston (1988).

\section{Site and Institutional Abbreviations}


Baynunah Formation specimens numbered with the prefix $A U H$ are curated by the Abu Dhabi Department of Culture and Tourism, while those with the prefix $N H M M$ (abbreviated $M$ in the text below) are curated by the Natural History Museum, London. Detailed information on all Baynunah fossil localities is given by Bibi et al. (this volume-b). Other mentioned sites are: $W M$ Adu-Asa Formation ('Western Margin' of the Middle Awash, Ethiopia), LT Lothagam (Kenya), NP Napudet (Turkana, Kenya), SH Samburu Hills (Kenya), TM Toros-Ménalla (Djourab, Chad). Main repository institutions are as follows: $C N R D$ Centre National de la Recherche pour le Développement (N’Djaména, Chad), KNM Kenyan National Museums (Nairobi, Kenya); NHM Natural History Museum (London, England), $N M L$ National Museum of Libya; $M N H N$ Muséum National d'Histoire Naturelle (Paris, France); TBI Turkana Basin Institute (Turkwel, Kenya).

\section{Systematic Paleontology}

CETARTIODACTYLA Montgelard, Catzeflis, \& Douzery, 1997

CETANCODONTA Arnason, Gullberg, Solweig, Ursing, \& Janke, 2000

HIPPOPOTAMOIDEA sensu Gentry \& Hooker, 1988

HIPPOPOTAMIDAE Gray, 1821

HIPPOPOTAMINAE Gray, 1821

ARCHAEOPOTAMUS Boisserie, 2005

Type species-Archaeopotamus lothagamensis (Weston, 2000). 
Other representatives-Archaeopotamus harvardi (Coryndon, 1977); A. aff. harvardi from Rawi ("pigmy hippo mandible, possibly Hexaprotodon imagunculus" in [Ditchfield et al. 1999: 131]; see Boisserie 2005); A. qeshta Boisserie, Schuster, Beech, Hill \& Bibi, 2017. Spatiotemporal distribution —Late Miocene to late Pliocene/early Pleistocene of Arabia and eastern Africa. Known from the Baynunah Formation, United Arab Emirates; Lothagam and Rawi in Kenya (Boisserie 2005); and possibly Manonga in Tanzania (Harrison 1997).

Emended diagnosis-Hexaprotodont hippopotamids differing from Kenyapotamus and earlier genera in displaying the trigonid pattern typical of the Hippopotaminae (i.e., lacking a developed metacristid, having an enlarged endometacristid and a postprotocristid reduced in comparison to the postparacristid). Differ from Kenyapotamus and the early hippopotamine material from Beticha (Chorora) by $\mathrm{P}^{3} /$ having distolingual cusps distinct from the cingulum, relatively deeper fossae and longer cristae, a smaller paraconule, and fewer conules/-ids. Differ from other hippopotamine genera in having: a mandibular symphysis more elongate relative to its width; an incisive alveolar process projecting rostrally relative to the canine processes; less lateral extension of the canine processes; a greater length of the lower premolar row relative to the length of the molar row; and gonial angle of the ascending ramus not laterally everted (modified from Boisserie, 2005).

ARCHAEOPOTAMUS QESHTA Boisserie, Schuster, Beech, Hill \& Bibi, 2017

1999 Hexaprotodon aff. sahabiensis; Gentry: 277.

2005 Archaeopotamus aff. lothagamensis; Boisserie: 18. 
Holotype-NHM M49464, mandible with eroded symphysis and teeth including left $\mathrm{P} / 3-\mathrm{M} / 3$ and right $\mathrm{P} / 4$ and $\mathrm{M} / 3$, collected by Peter J. Whybrow in 1982 .

Distribution - Currently known only from the Baynunah Formation. Faunal comparisons suggest an age between 8 Ma and 6 Ma (Hill 1999; Bibi et al. 2006; Bibi et al. 2013), possibly between 7.7 and 7.0 Ma (Peppe et al., this volume).

Differential diagnosis — Small-sized hippopotamid, intermediate in size between Archaeopotamus lothagamensis and Archaeopotamus harvardi. Differs from other hippopotamines with known mandibular morphology in having a symphysis more elongate relative to its width, and in having a lower premolar row $\left(\mathrm{P} /{ }_{2}-\mathrm{P} / 4\right)$ less than $10 \%$ shorter than the molar row $\left(\mathrm{M} /{ }_{1}-\mathrm{M} / 3\right)$. Further differs from other late Miocene hippopotamines by the largest lower incisor being I/2. Further differs from larger late Miocene hippopotamines in: $\mathrm{I}^{1 /}$ and $\mathrm{I}^{2} /$ being subequal in size and larger than $\mathrm{I}^{3} / ; \mathrm{I}^{2} /$ being labiolingually compressed; and in lower premolar rows $\left(\mathrm{P} /{ }_{1}\right.$ included) displaying almost no rostral divergence from each other. Further differs from other species of Archaeopotamus in $\mathrm{I} / 1$ and $\mathrm{I} / 2$ being the ventralmost and dorsalmost lower incisors, respectively (observed in rostral view). Further differs from $A$. harvardi in having less procumbent lower incisors (from Boisserie et al., 2017a).

Material-Hamra: AUH 2, incisor fragment (HMR 1); AUH 5, fragmentary left astragalus (HMR 1); AUH 44, right astragalus (HMR 5); AUH 154, right metacarpal V (HMR 1); AUH 369, left P/1 (HMR 1); AUH 457, partial mandible with eroded symphysis, left \& right I/ $/ 1-\mathrm{C} / 1$ 
roots, broken right $\mathrm{P} / 2, \mathrm{M} /{ }_{1}-\mathrm{M} / 3$, roots of other teeth (HMR 1); AUH 1241, left metacarpal II (HMR 1); AUH 1793, left M/1 (HMR 6). Jebel Dhanna: AUH 36, right M³/(JDH 5); AUH 664, left P/1, germ (JDH 5); AUH 420, right metatarsal III, fragment (JDH 4); AUH 421, $\mathrm{P}^{4}$, fragmentary (JDH 4). Shuwaihat: AUH 53, right metacarpal III (SHU 1); AUH 83, proximal phalanx III or IV (SHU 1); AUH 96-97, right metacarpal III (SHU 1); AUH 247, left metatarsal III (SHU 4); AUH 481, juvenile mandible with partial symphysis, most of right corpus and fragment of left corpus, right $\mathrm{I} /{ }_{1}-\mathrm{I} / 2$, left $\mathrm{I} / 2-\mathrm{I} / 3$, left $\&$ right $\mathrm{C} /{ }_{1}$, left $\mathrm{P} /{ }_{2}-\mathrm{P} / 4$, right $\mathrm{P} /{ }_{2}-\mathrm{P} / 3$, and $\mathrm{dP} / 4$ (SHU 4). Thumayriya: AUH 243, right metatarsal III (THM 1). Kihal: AUH 262, $\mathrm{P}^{4} /$, fragmentary (KIH 1); AUH 1252 right astragalus, eroded (KIH 4). Harmiyah: AUH 359, two enamel fragments from left upper premolar and right upper canine (HAR 1). Jebel Barakah: AUH 368, left astragalus (JBR 1); NHM M49464, holotype mandible with eroded symphysis, left $\mathrm{P} /{ }_{3}-\mathrm{M} / 3$, right $\mathrm{P} / 4$ and fragmentary $\mathrm{M} / 3$ (JBR 2); $\mathrm{NHM} \mathrm{M49465,} \mathrm{right} \mathrm{P}^{3} /(\mathrm{JBR} 2)$. Gerain alAysh: AUH 1532, right M²/ (GAA 2); AUH 1561, right metacarpal IV (GAA 3); AUH 1564, left P1/ (GAA 3); AUH 1794, proximal phalanx III or IV (GAA 2); AUH 1795, proximal phalanx III or IV (GAA 2). Baynunah North: AUH 1614, right premaxilla with $\mathrm{I}^{3} /$ and roots of $\mathrm{I}^{1} /-\mathrm{I}^{2} /$, broken (BYN 1). Ruwais Central: AUH 1731, left I²/ (RUW C); AUH 1736, left astragalus, fragmentary (RUW C).

Some additional specimens are referred to Archaeopotamus cf. qeshta. Shuwaihat: AUH 29, canine, fragment (SHU 1); AUH 84, central metapodial, fragment (SHU 1); AUH 110, lower molar, fragment (SHU 1); AUH 248, lateral metapodial, distal fragment (SHU 4); AUH 795, right dP/3 (SHU 2). Hamra: AUH 150, right tibia, distal fragment (HMR 3); AUH 339, intermediate phalanx II or V (HMR 5); AUH 1242, metapodial, fragmentary and eroded (HMR 1); AUH 1714, tooth, fragmentary and distorted (HMR 5). Jebel Dhanna: AUH 288, right fibula, distal fragment (JDH 3); AUH 292, upper incisor, apical fragment (JDH 3). Ras al Qal'a: 
AUH 429, axis (RAQ 1). Jebel Barakah: AUH 446, left C/1, fragment (JBR 2). Thumayriya: AUH 478, intermediate phalanx II or V (THM 1). Jebel Mimiyah: AUH 1278, lower incisor, fragmentary (MIM 1). Baynunah North: AUH 1619, left radius-ulna (BYN 3). Ruwais Central: AUH 1730, left hamate (RUW C); AUH 1741, proximal phalanx II or V (RUW C).

\section{PLACE FIGURE 15.1 ABOUT HERE; WIDTH = 2 COLUMNS}

Some of the material reported by Gentry (1999) cannot be attributed with certainty to Archaeopotamus qeshta and is treated here as Hippopotamidae indet. or cf. Hippopotamidae.

Hippopotamidae indet.: AUH 31, tooth fragments (SHU 1); AUH 49, right scapula, proximal fragment (HMR 5); AUH 57, incisor fragment; AUH 59, left femur, distal fragment (SHU 1); AUH 60, tooth fragments (SHU 1); AUH 66, cervical vertebra, fragment (SHU 1); AUH 68, left humerus, distal fragment (SHU 1); AUH 92, tooth fragments (SHU 1); AUH 98, right radius, distal fragment (SHU 1); AUH 99, maxilla with $\mathrm{M}^{3}$ / frag (SHU 1); AUH 103, ilium fragment (SHU 1); AUH 105, thoracic vertebra, fragments (SHU 1); AUH 118, right scapula, proximal fragment (SHU 1); AUH 133, ischium fragment (SHU 2); AUH 170, right lunate (HMR 1); AUH 224, cervical vertebra, fragment (SHU 4); AUH 235, mandible fragments (SHU 4); AUH 252, right cuneiform (SHU 4); AUH 253, right radius, proximal fragment (SHU 4); AUH 293, left rib, dorsal fragment (JDH 3); AUH 431, atlas, fragmentary (RAQ 1); AUH 443, right scapula, fragment (JBR 2); AUH 497, right humerus, fragmentary (JDH 3); AUH 498-499, right tibia, proximal fragments (JDH 3); AUH 637, right astragalus, fragment (BJW 1, Bin Jawabi); AUH 828, left tibia, slightly eroded (SHU 3); AUH 844, left metacarpal V, fragmentary and eroded (SHU 4); AUH 861, axis corpus, fragmentary (SHU 9); AUH 863, upper molar, 
fragmentary and very worn (SHU 9); AUH 870, right metatarsal V, fragmentary (SHU 10); AUH 1041, juvenile left calcaneum, fragmentary and eroded (SHU 3).

cf. Hippopotamidae: AUH 37, incisor, fragment (JDH 5); AUH 312: incisor, fragment (KIH $1)$.

\section{Comparative Description}

\section{Mandible}

The two best-preserved mandibular specimens of Archaeopotamus qeshta are the holotype mandible M49464 and the fragmentary mandible AUH 457 (Fig. 15.1). The latter displays a damaged symphysis, lacks most of the ascending rami, and retains a broken right $\mathrm{P} / 2$ and partial right $\mathrm{M} / 1_{1}-\mathrm{M} / 3$. Both specimens are adult, displaying $\mathrm{M} / 3$ s with advanced wear. The two specimens differ mostly in that AUH 457 is more robust (with notably greater corpus thickness), has a longer symphysis and canine processes that project slightly more laterally (Fig. 15.1, Table 15.1). These moderate differences are compatible with sexual dimorphism in the living species Hippopotamus amphibius and Choeropsis liberiensis (see Weston 1997, Boisserie 2002). Following this interpretation, AUH 457 and M49464 would represent the male and female morphotypes, respectively. AUH 481 is a juvenile symphysis preserving a damaged symphysis and most of the right corpus with $\mathrm{P} / 2-\mathrm{P} / 3$ erupting and $\mathrm{dP} / 4$ in advanced wear. It is only slightly smaller in size than the two adult mandibles, but markedly narrower (Fig. 15.2, Table 15.1).

\section{PLACE TABLE 15.1 ABOUT HERE}

These three mandibles are characterized by symphyses that are greatly elongated relative to their width, A. qeshta displaying the longest mandibular symphysis relative to its width within the Hippopotaminae (Table 15.3a). Only Kenyapotamus ternani Pickford, 1983 displays a relatively 
more elongate symphysis, documented by specimen KNM-NP 64505 from Napudet (Boisserie et al. 2017b). The Baynunah symphyses are also relatively shallow compared to the symphysis of Hexaprotodon garyam (Fig. 15.3a). This higher symphysis is related to the greater robustness of the nuchal part of the symphysis combined with the greater inclination of the incisive alveolar process in Hex. garyam (Fig. 15.4).

\section{PLACE FIGURE 15.2 ABOUT HERE; WIDTH = 1 COLUMN}

In sagittal cross-section, the incisive alveolar process of AUH 457 displays a continuous ventral slope as in A. lothagamensis, A. aff. harvardi from Rawi, and K. ternani, differing from Hex. garyam, Hex. sivalensis, and $A$. harvardi in which a ventral shift in curvature clearly differentiates the process from the nuchal portion of the symphysis (Fig. 15.4). M49464 displays a similar ventral shift in curvature, but this lies closer to the rostral extremity of the symphysis and is less marked than in A. harvardi and Hex. garyam (Fig. 15.4). Overall, the thickness of the symphysis in sagittal cross-section in M49464 and AUH 457 is relatively greater than that of $A$. lothagamensis and A. harvardi. AUH 481 is more similar to A. harvardi in the thinness and differentiation of the incisive alveolar process (Fig. 15.4).

\section{PLACE FIGURE 15.3 ABOUT HERE; WIDTH = 2 COLUMNS}

The incisive alveolar process of $A$. qeshta also displays a more or less marked sagittal depression on its ventral side (Fig. 15.1c). This is wide in AUH 457, narrow and well-marked in M49464, and narrow and shallow in AUH 481. Such a depression is not found in other specimens attributed to Archaeopotamus or in Hex. garyam.

In dorsal view, the incisive alveolar process projects rostrally to the canine alveoli, as in other species of Archaeopotamus. The two adults are damaged in this area (Fig. 15.1), M49464 suggesting a more or less straight rostral border of this process. However, AUH 481, better preserved, has a rostral border that is curved in dorsal view (Fig. 15.2a), as in KNM-NP 64505 
attributed to Kenyapotamus. The rostral border in A. harvardi and Hex. garyam is more or less straight.

\section{PLACE FIGURE 15.4 ABOUT HERE; WIDTH = 2 COLUMNS}

In rostral view, the incisor alveolar plane in $A$. qeshta is displaced, the $\mathrm{I} / 1$ being set more ventrally than the $\mathrm{I} / 3$, and the $\mathrm{I} / 2$ more dorsally than the two others (Fig. 15.1c). This differs from A. lothagamensis, in which the alveoli are more or less aligned with a slighter dorsal shift of the $\mathrm{I}^{2}$, and from $A$. harvardi, in which the alveoli form a shallow arc that is dorsally convex. Hexaprotodon garyam is similar to $A$. qeshta in retaining a more dorsal $\mathrm{I} / 2$, but the $\mathrm{I} / 1$ and the $\mathrm{I} / 3$ tend to be aligned on the same horizontal level. The most similar arrangement to that seen in $A$. qeshta is observed in K. ternani from Napudet, the $\mathrm{I} / 3$ being even more dorsally-shifted, close to the level of the $\mathrm{I} / 2$.

In lateral view, the incisors of M49464 emerge upward from the incisive alveolar process at an angle of about $36^{\circ}$ to the cheek tooth alveolar plane. This angle is smaller for the flatter symphysis of AUH 481 (about $24^{\circ}$ ). In $A$. harvardi, the incisors are more procumbent, with the same angle being less than $10^{\circ}$. The condition in A. lothagamensis is uncertain because the main specimen (holotype KNM-LT 23839) is missing its incisors; the alveoli and the inclination of the symphysis suggest a condition closer to that of $A$. qeshta than to $A$. harvardi. Hex. garyam has angle values close to those of $A$. qeshta, ranging between $20^{\circ}$ and $30^{\circ}$.

The canine processes of AUH 457 are slightly inflated laterally, bulging out of the corpus. This is not the case in M49464, in which the canine processes are in continuity with the corpus (Fig. 15.1). The postcanine constriction of the mandible is not very marked. This morphology again recalls $K$. ternani from Napudet and A. lothagamensis. Yet, in dorsal view, the main axis of the canine alveoli forms a greater angle with the parallel cheek tooth rows in $A$. qeshta (ca. $43^{\circ}$ to $45^{\circ}$ ) than in $A$. lothagamensis $\left(\mathrm{ca} .31^{\circ}\right)$. In $A$. harvardi and Hex. garyam, the canine processes 
extend more laterally than in A. qeshta and define a more marked postcanine constriction, but this extension concerns also the corpus and the mesial cheek teeth that diverge laterally.

Hexaprotodon garyam also displays a moderate rostral extension of the canine processes, but this is not the case in $A$. qeshta and in other representatives of Archaeopotamus, except $A$. aff. harvardi from Rawi.

In rostral view, the canine alveoli of $A$. qeshta are subparallel to the line joining the right and left I/3. In Hex. garyam, the canine alveoli are rostro-laterally oriented, forming an angle of ca. $40^{\circ}$ with the incisor line. Archaeopotamus harvardi presents an intermediate condition.

The symphyseal dorsal plane of A. qeshta is narrow as in A. lothagamensis and K. ternani and does not present a rostral widening as in $A$. harvardi, Hex. garyam, and $A$. aff. harvardi from Rawi. Also unlike A. harvardi and Hex. garyam, the symphyseal dorsal plane is transversely curved between the canines, this curvature increasing nuchally between the premolars. It is very deep in the adults, but shallower in AUH 481. A relatively shallow symphysis was also described in a large juvenile from Lothagam (indeterminate level), tentatively attributed to a species larger than A. harvardi (KNM-LT 79: Weston 2003). The occurrence of similar morphology in a juvenile from Baynunah, as well as in another juvenile of similar biological age from the lower Pliocene of Kossom Bougoudi in Chad (KB 3-97-201: Boisserie et al. 2003), suggests that the depth of the symphysis may be subject to ontogenetic variation in early hippopotamines.

In adult specimens of $A$. qeshta, the nuchal portion of the symphysis is shallow and forms a $\mathrm{V}$ with the corpora in dorsal and ventral views (Fig. 15.1a,e), whereas AUH 481 displays a U shape (Fig. 15.2a). This feature also tends to be related to ontogenetic stage as well as to the extension of the canines within the symphysis, which is usually more marked in males in the extant species (Boisserie 2002). 
Ventrally, the symphysis of $A$. qeshta is markedly convex, as in K. ternani from Napudet and A. lothagamensis. Archaeopotamus harvardi and some specimens of Hex. garyam have flatter ventral surfaces. More caudally, the three specimens of $A$. qeshta also display large depressions for genioglossal insertions extending onto the ventral side of the symphysis.

In $A$. qeshta, the mandibular corpus is about the same height below the premolars as below the molars, differing from $A$. harvardi in which the corpus is deeper under the molars, and from most specimens of Hex. garyam that display a greater depth under the premolars. In lateral view, the ventral transition with the ascending ramus is marked by a deep vascular incisure (Fig. 15.1d,f), as in $A$. lothagamensis and some representatives of $A$. harvardi. This contrasts with the rectilinear ventral edge of the corpus in Hex. garyam. Caudally, the angular process of A. qeshta is thin and oriented in the same plane as the corpus (Fig. 15.1a,e), as in A. harvardi, and unlike the everted process observed in Hex. garyam.

\section{PLACE FIGURE 15.5 ABOUT HERE; WIDTH = 2 COLUMNS}

\section{Rostral Dentition}

Upper incisors are documented by AUH 1614, an eroded, fragmentary premaxilla that is actually the only hippopotamid cranial remain from the Baynunah Formation. It includes broken $\mathrm{I}^{1 /}$ and $\mathrm{I}^{2} /$ and a complete $\mathrm{I}^{3} /$. The three incisors present a continuous band of thick, striated enamel. This band is mesiolabial on $\mathrm{I}^{1}$, covering the labial side and extending onto the mesial and distal sides on the $\mathrm{I}^{2} /$, and restricted to the labial side of $\mathrm{I}^{3} / . \mathrm{I}^{1} /$ and $\mathrm{I}^{2} /$ are subequal in cross-sectional size and about 56\% larger than $\mathrm{I}^{3} /$, whereas in A. harvardi, Hex. garyam, and Hippopotamidae indet. from $\mathrm{WM}, \mathrm{I}^{2} /$ is on average larger than $\mathrm{I}^{1 /}$ and $\mathrm{I}^{3} /$ is less reduced compared to the $\mathrm{I}^{1}$, or similar in cross-sectional size (Table 15.2). The lingual side of these incisors is more or less flat, the $\mathrm{I}^{2} /$ having a longitudinal groove between two crests. $\mathrm{I}^{2} /$ is labiolingually compressed unlike in $A$. 
harvardi, Hex. garyam, and Hippopotamidae indet. from WM (Table 15.2). $\mathrm{I}^{1 /}$ and $\mathrm{I}^{3} /$ have close linguolabial and mesiodistal diameters (Table 15.3). $\mathrm{I}^{3} /$ presents an apical, beveled wear facet that extends to the distal side, the edge of the facet being smoothed by this distal wear.

\section{PLACE TABLE 15.2 ABOUT HERE}

AUH 1731 (Fig. 15.5a) is an isolated, complete $\mathrm{I}^{2} /$ that is similar to the AUH $1614 \mathrm{I}^{2} /$ in being strongly compressed labiolingually, in possessing a labial band of enamel extending along the entire tooth length, and in displaying a lingual longitudinal groove. This tooth presents an apical, undulating wear facet cutting the main axis of the tooth at a $45^{\circ}$ angle. The base is open, but the linguolabial diameter tapers markedly from crown to base, suggesting that this tooth may not have been ever-growing as in the extant Hippopotamus amphibius. AUH 2 is an apical fragment of another $\mathrm{I}^{2} /$ with the exact same features.

The upper canine is known only by a ca. 6 cm-long enamel fragment (included in AUH 359). This fragment displays the curvature that is usually observed in late Miocene hippopotamine canines.

\section{PLACE TABLE 15.3 ABOUT HERE}

Within the lower incisors of Archaeopotamus qeshta, I/2 displays the largest cross-section, as in K. ternani and A. lothagamensis (Tables 15.2 and 15.4). Yet, the difference is less marked between $\mathrm{I} /{ }_{1}$ and $\mathrm{I} / 2$ than in those latter species, and in A. lothagamensis, the $\mathrm{I} / 3$ is by far the largest lower incisor. In A. harvardi, A. aff. harvardi from Rawi, Hex. garyam, and Hexaprotodon? sahabiensis, $\mathrm{I} /{ }_{1}$ is the largest lower incisor (Table 15.2). In AUH 481 (Fig. 15.2), the preserved incisors present an enamel cap that has a long lingual extension, as seen in the second specimen attributed to A. lothagamensis (KNM-LT 23879, see Weston 2000).

\section{PLACE TABLE 15.4 ABOUT HERE}


The lower canine morphology of $A$. qeshta does not depart significantly from that of the other late Miocene hippopotamines: the canine is ever-growing, extending within the symphysis from alveolus to the nuchal part; its cross-section is bean-shaped with the flat-to-concave side being mesial; its lingual side (with contact facet for the upper canine) is not covered by enamel. The enamel is smooth to finely wrinkled. On the distal surface, the enamel is relatively thick compared to the canine dimensions. Relatively thick distal enamel, accounting for approximately 6 to $8 \%$ of the mesiodistal width of the section, is found in other species of Archaeopotamus, whereas in Hex. garyam the enamel is thinner.

\section{Postcanine Dentition}

Premolar and molar dimensions are provided in Tables 15.5, 15.6, 15.7, and 15.8. The postcanine dentition of Archaeopotamus qeshta appears close in size to that of Hexaprotodon sahabiensis. It is larger in size than that of $K$. ternani, A. lothagamensis, and A. aff. harvardi from Rawi (except for $\mathrm{P}^{4} /$ length in the latter,). It overlaps with the lower range of the larger $A$. harvardi and Hex. garyam, as shown for $\mathrm{M} / 3$ on Fig. $15.3 \mathrm{~b}$, as well as with the lower range of Hippopotamidae indet. from WM in most cases (see Tables 15.5 to 15.8 ) .

\section{PLACE TABLES 15.5, 15.6, 15.7, AND 15.8 ABOUT HERE}

$\mathrm{P}^{1} /$ of Archaeopotamus qeshta is known through a fragmentary left specimen, AUH 1564 . This is a robust, permanent tooth with thick, strongly pustulate enamel on its mesial wall. It has two roots that are fused by a thin wall of dentine labially. This morphology is also observed in other late Miocene hippopotamines such as $A$. harvardi and Hex. garyam. $\mathrm{P}^{2} /$ is not known.

M49465 is an isolated right $\mathrm{P}^{3} /$ with advanced wear and missing a fragment of its apex (Fig. 15.5b). In occlusal view, this tooth forms two lobes separated by a marked constriction. It is wide, with a strong cingulum present on all sides but attenuating at the labial indentation of the 
cervix. The massive paracone is flanked by four distolingual accessory cusps in a position equivalent to a 'protocone' (see definition by Boisserie et al. 2010), a condition frequently observed in A. harvardi and Hex. garyam. These conules are distinct from the well-expressed distolingual cingulum, a condition differing from that observed in Kenyapotamus and typical of most hippopotamines. The valley separating the paracone and the distolingual cusps is narrow, as in Kenyapotamus and some of the hippopotamine material from the late Miocene of Chorora (Boisserie et al. 2017c), but unlike any other hippopotamines. At least one strong basal postparaconule is present on the postparacrista, and wear may have obliterated more apical postparaconules. The roots are massive.

$\mathrm{P}^{4} /$ is documented by two fragmentary specimens. The most complete one, AUH 262 (Fig. $15.5 \mathrm{c}$ ), is the lingual half of a $\mathrm{P}^{4} /$, tentatively sided as from the right side. It displays a strong and high crenulated cingulum. The protocone is crescentic; it does not display deep fossae, as in Kenyapotamus and some specimens of A. harvardi, and unlike in Hex. garyam. Similarly to Kenyapotamus and some specimens of Hex. garyam, the paracone does not present a welldeveloped endoparacrista,. This contrasts with the strong endoparacrista observed in A. harvardi and most representatives of Hex. garyam.

Two upper molars are known for $A$. qeshta. The first one is an isolated right $\mathrm{M}^{2} /$ with incipient wear on the mesial cusps (AUH 1532, Fig. 15.5e). This tooth is square-shaped, as in most hippopotamines. Its cingula are well-developed mesially and distally, but reduced on the lateral sides. The cusps display a crest pattern similar to that observed in A. harvardi and Hex. garyam. The preprotocrista is inflated, the bulging recalling an incipient paraconule. There are no ecto- or endostyles, or cristyles.

The other upper molar is an unworn, isolated right $\mathrm{M}^{3}$ / (AUH 36, Fig. 15.5f). This tooth has a strongly crenulated cingulum that attenuates only on the labial side of the paracone. The cristae 
are long and sharp, with the preparacristae and postmetacristae strongly curved labially. The preprotocrista joins a small paraconule, as seen in some specimens of $A$. harvardi and Hex. garyam, but rarely in later taxa. A similar conule is adjacent to the distostyle. There is an entostyle and an ectostyle unusually shifted distally to the labial valley. The most remarkable feature of this tooth is the organization of the metaconule cristae. The premetacristule is relatively short and straight. Mesially, it joins the postprotocristae on its lingual wall. Distally, it forms an apical loop with a crista in labial position as an endometacristule. This endometacristule bifurcates in two long branches before reaching the lingual wall of the metacone. The mesial branch is straight and directed toward the extremity of the postprotocrista. Its distal branch is thicker and shorter and joins the distal conule near the distostyle. To our knowledge, such a bifid morphology of a molar crest is only found in a pre-entocristid of a specimen from the latest Miocene of Chorora, which is identified as an indeterminate hippopotamine.

This $\mathrm{M}^{3}$ / displays a full crown height, and its hypsodonty index $\mathrm{H}(100 \times$ paracone height / mesial width) is reported in Table 15.7. This tooth is higher-crowned than in Kenyapotamus, and has a crown height equivalent to those of $A$. harvardi and Hex. garyam. One $\mathrm{M}^{3} /$ from $\mathrm{WM}$ is markedly higher-crowned.

$\mathrm{P} / 1$ is known from two isolated specimens. AUH 369 is a moderately worn, single-rooted left $\mathrm{P} /{ }_{1}$. The paraconid is fang-like with a minute conulid on the base of the postparacristid. A cingulid is present only on the mesial side. The root has a single lobe and it is large compared to the crown. AUH 664 is a crown of another left $\mathrm{P} / 1$ (Fig. 15.5d). It is unworn and probably unerupted. It is more labiolingually compressed than AUH 369. It displays a higher distolingual conulid with four marked triangular indentations, a morphology also observed in $A$. lothagamensis (KNM-LT 23879). The P/1 alveoli on M49464 and AUH 457 also indicate single 
rooted teeth (Fig. 15.1a,e). In the latter specimen, the alveoli are very shallow, suggesting that these teeth may be lost in advanced age.

Compared to other hippopotamines, in $A$. qeshta the $\mathrm{P} /{ }_{2}-\mathrm{P} /{ }_{4}$ row is long relative to the molar row (Table 15.9). This is notably marked compared to Hex. garyam, but also true compared to other species of Archaeopotamus. Only Kenyapotamus displays a somewhat longer $\mathrm{P} /{ }_{2}-\mathrm{P} / 4$ row. These teeth display a morphological gradient that is typical for early hippopotamines: the metaconid is incipient and distally shifted in $\mathrm{P} / 2$; large, high, and lingual on the $\mathrm{P} / 4$; intermediate or as in $\mathrm{P} / 2$ in the $\mathrm{P} / 3$. The mesial and distal cingulids are low and thin in $\mathrm{P} / 2$ and become larger and higher in the distal premolars. $\mathrm{P} / 4$ displays both well-expressed entoconid and hypoconid (Fig. 15.1b), whereas the former can be missing on $\mathrm{P} / 2$ and $\mathrm{P} / 3$ (AUH 481). A distal fragment of a lower premolar associated with M49464 is unusual in having a marked entoconid, a labially shifted hypoconid and, in addition, a conulid basal to the entoconid looking like a cingulid. It differs from $\mathrm{P} / 4$ in this morphology and in being more slender, and is better interpreted as the right $\mathrm{P} / 2$ or $\mathrm{P} / 3$.

\section{PLACE TABLE 15.9 ABOUT HERE}

The lower molars of $A$. qeshta (Fig. 15.1b) have a trigonid organization typical of Hippopotaminae, observable on the M/3 of M49464 and on AUH 1793 (left M/1) preserved at NHM: the preprotocristid directed toward the mesiostylid and the endometacristid joining the lingual wall of the preprotocristid. The postprotocristid is short and joins the labial wall of the long postmetacristid that connects to the prehypocristid. The entoconid is reduced. On the $\mathrm{M} / 3$, the hypoconulid has relatively short cristids, as in A. lothagamensis, except the prehypocristulid, which is inflated into a prehypoconulid.

\section{Autopodium}


Hippopotamid postcranial elements from the Baynunah Formation were described in detail by Gentry (1999), and the present account focuses on the relative dimensions of astragali, metapodials, and phalanges attributed to Archaeopotamus qeshta in this contribution. The astragali of $A$. qeshta are morphologically similar to those of hippopotamids. Their general proportions fit the ranges observed in Kenyapotamus, A. harvardi, Hex. garyam, and Hippopotamidae indet. from WM (Table 15.10), but the Baynunah specimens are on average somewhat narrower, especially compared with $A$. harvardi and the Adu-Asa hippopotamid. Astragalar dimensions are a good proxy for body mass in artiodactyls (Martínez and Sudre 1995), and this element was used to provide a body mass estimate for A. qeshta (Table 15.10). This species appears to be of moderate size for a hippopotamid, ca. $600 \mathrm{~kg}$, i.e., on average half to one third the mass of the common species from Lothagam (A. harvardi), TM (Hex. garyam), and WM. It is however twice the mass of Kenyapotamus.

\section{PLACE TABLE 15.10 ABOUT HERE}

The relatively small dimensions of the Baynunah hippopotamid compared to Hex. garyam, $A$. harvardi and Hippopotamidae indet. from WM are confirmed by metapodial and phalangeal dimensions (Tables 15.11, 15.12, 15.13, and 15.14). A metacarpal V attributed to $A$. lothagamensis is smaller than that of $A$. qeshta (Table 15.13), again supporting a smaller size of the former species compared to A. qeshta. Interestingly, the metapodials of A. qeshta are more robust than those of $A$. harvardi, although the later species is larger (Table 15.11). Compared with $A$. harvardi, the lateral metapodials are also slightly more elongated relatively to the central ones. With regard to these proportions, A. qeshta is more similar to Hex. garyam. Both Hex. garyam and Hippopotamidae indet. from WM have larger phalanges than in A. qeshta, but in the WM they are wider relative to their length than in the Baynunah species (Table 15.14).

PLACE TABLES 15.11, 15.12, 15.13, AND 15.14 ABOUT HERE 


\section{Phylogenetic Analysis}

A morphological character matrix was initially assembled by Boisserie et al. (2010), refined by Orliac et al. (2010) and further extended by Alloing-Séguier et al. (2014) and Lihoreau et al. (2015) in order to test the phylogenetic relationships between Hippopotamidae, anthracotheres, Suina, and other cetartiodactyls. This matrix so far combines the largest number of fossil hippopotamoids and other cetartiodactyls in a phylogenetic investigation to date (164 craniodental characters for 58 taxa; outgroups: Homacodon, Gujaratia, and Bunophorus). Here we include Archaeopotamus qeshta as well as new hippopotamid material of Kenyapotamus from the middle Miocene of Napudet (Boisserie et al. 2017b) and from the middle and upper beds at Chorora (Suwa et al. 2015; Katoh et al. 2016; Boisserie et al. 2017c). The matrix was additionally modified from that of Lihoreau et al. (2015) by changing the coding of one character (character 120: connection of premetacrista and postprotocrista). Polymorphic states were coded as: A (01), B (02), C (012), D (12), E (13). Variable states were coded as: F $\{01\}, \mathrm{G}\{02\}, \mathrm{H}\{23\}$. The matrix and tree nexus files are available at http://morphobank.org/permalink/?P3978 via Morphobank (project 3978).

A parsimony analysis was performed using PAUP 4.0a150 (Swofford 2002). The search was heuristic, treated multistate characters as polymorphisms, and was run for 1,000 replicates with random addition sequence. The analysis resulted in 33 trees of 1091 steps. The resulting consensus tree (Fig. 15.6) resolves the relationships of Hippopotamidae by anchoring this family within the archaic bothriodontine group that mostly evolved in Africa and that includes 
Bothriogenys and Brachyodus. This agrees with the general interpretation of the position of Epirigenys as sister-group of the clade Hippopotamidae (Lihoreau et al. 2015). Within this clade, the relationships between kenyapotamines are not resolved. In contrast, the Hippopotaminae form a clade (Fig. 15.6d) supported by multiple dental features including the presence of more than two postparaconules (character 80), the low cingula on the upper molars (character 101) and the organization of the trigonid (notably character 39). Archaeopotamus is paraphyletic, with $A$. qeshta being the sister-group of $A$. harvardi + Hexaprotodon garyam. The latter two species are united only by the $\mathrm{I} /{ }_{1}$ being the largest lower incisor, while in $A$. qeshta it is the $\mathrm{I} / 2$ (character 4 ).

$$
\text { PLACE FIGURE 15.6 ABOUT HERE; WIDTH = } 1 \text { COLUMN }
$$

\section{Discussion and Conclusions}

\section{The Baynunah Hippopotamid and its Relationships with Hexaprotodon? sahabiensis}

In summary, the Baynunah hippopotamid material belongs to a small-sized species intermediate in size between Archaeopotamus lothagamensis and Archaeopotamus harvardi. There is no evidence for the presence of more than one hippopotamid species in the Baynunah Formation. The main differences of the Baynunah hippopotamid from other hippopotamines with known mandibular morphology are that it displays a symphysis more elongate relative to its width and a premolar row $\left(\mathrm{P} /{ }_{2}-\mathrm{P} / 4\right)$ less than $10 \%$ shorter than the molar row $\left(\mathrm{M} /{ }_{1}-\mathrm{M} / 3\right)$. The rostral dentition is also quite distinctive. $\mathrm{I} / 2$ is the largest lower incisor, whereas in other late Miocene hippopotamines it is $\mathrm{I} / 1$ or $\mathrm{I} / 3$. Unlike other species of Archaeopotamus, $\mathrm{I} / 1$ and $\mathrm{I} / 2$ are the most ventral and dorsal lower incisors, respectively, and the lower incisors are less procumbent than in $A$. harvardi. Unlike the larger late Miocene hippopotamines (notably Hexaprotodon garyam and $A$. harvardi), $\mathrm{I}^{2} /$ is labiolingually compressed, and $\mathrm{I}^{1} /$ and $\mathrm{I}^{2} /$ are 
subequal in size and larger than $\mathrm{I}^{3}$. The Baynunah material further differs from these large hippopotamines in displaying almost no rostral divergence between its left and right lower premolar rows $(\mathrm{P} / 1$ included $)$.

In his initial description of the hippopotamid material from the Baynunah Formation, Gentry (1999) observed that this material exhibited fewer morphological differences with Hex.? sahabiensis from Sahabi (Libya) than other species, and attributed it to 'Hexaprotodon aff. sahabiensis'. In describing 'Hexaprotodon' lothagamensis, Weston (2000) recognized more affinities between this new species and the Baynunah hippopotamid. Consequently, in a general revision of the phylogeny and systematics of the Hippopotamidae (Boisserie 2005), the demonstration that Hexaprotodon was a paraphyletic wastebasket taxon led to the establishment of the genus Archaeopotamus for hippopotamines displaying a relatively long symphysis, and to the proposition that the Baynunah hippopotamid should be referred to Archaeopotamus aff. lothagamensis. In light of the above description of the new material found in the Baynunah Formation and of the reexamination of the older material (Gentry 1999), Boisserie et al. (2017a) formally recognized the Baynunah hippopotamid as a distinct species, Archaeopotamus qeshta.

The lack of direct affinities between A. qeshta and Hex.? sahabiensis is confirmed thanks to the recovery in the NML of additional Sahabi material described by Pavlakis (2008). The Libyan form has a clearly shorter symphysis and a more reduced I/2. Its approximate symphyseal crosssection (see Fig. 15.4) is also quite distinct from any other late Miocene hippopotamid, but the pictures published by Pavlakis (2008) suggest that it could be somewhat distorted. The affinities of Hex.? sahabiensis remain obscure. Unfortunately, its holotype specimen is a partial corpus with $\mathrm{P} /{ }_{4}-\mathrm{M} / 3$ (Gaziry 1987), i.e., a part of the mandible bearing few diagnostic features, and the original diagnosis does not present features that distinguish it from other late Miocene forms. The NML symphysis may have some morphological affinities with Hex. garyam from Chad (Fig. 
15.3a and see illustrations provided by Pavlakis 2008), but dimensions available for various specimens of Hex.? sahabiensis suggest that it could be a smaller species (see Tables 15.1 and 15.8).

\section{Phylogenetic Placement}

Archaeopotamus can be described as a genus combining a Kenyapotamus-like mandibular morphology with a dental morphology similar to that of late Miocene-early Pliocene hippopotamines. It is therefore tempting to identify the late Miocene representatives of Archaeopotamus, and notably its somewhat more derived, larger species $A$. harvardi, as the stem group of later hippopotamines (Harrison 1997; Weston 2000, 2003). In having a shallower symphysis (Fig. 15.3a) and a relatively longer premolar row (Table 15.9), Archaeopotamus qeshta is more like the earlier Kenyapotamus than A. lothagamensis. Following our phylogenetic analysis, in which Kenyapotamus is basal to a paraphyletic Archaeopotamus (in agreement with Boisserie et al. 2010; Lihoreau et al. 2015) and A. qeshta is the sister-group of a clade comprising A. harvardi and Hexaprotodon garyam from central Africa (Fig. 15.6), the mandibular morphology of the Baynunah species could be interpreted (contra Boisserie 2005) as the most archaic within Archaeopotamus and all hippopotamines for which mandibular morphology is known.

However, the situation may be more complex as a result of the diversity generated during the Hippopotamine Event, not restricted to Archaeopotamus (Boisserie et al. 2011). Other late Miocene species roughly contemporary with $A$. qeshta display more derived mandibular morphologies, such as Hex. garyam (see Boisserie et al. 2005a) and the tetraprotodont Hex.?

crusafonti (Aguirre 1963) from southern Europe (Lacomba et al. 1986). In addition, the early Pliocene Saotherium mingoz (Boisserie et al. 2003) and the extant Choeropsis liberiensis (Morton 
1849) have more derived mandibular morphology but combine relatively short symphyses with some cranial traits seemingly more primitive than those of A. harvardi and Hex. garyam, indicating that their lineage may root even deeper within the Hippopotamine Event than Archaeopotamus.

Our analysis relied on craniodental characters and did not consider a large number of hippopotamine taxa. Further analyses of the relationships among these different hippopotamine lineages should continue to expand the array of skeletal characters and hippopotamid taxa considered. The full description of $A$. qeshta fulfills an additional step in this regard.

\section{Paleobiogeography and Paleoecology}

Another interesting aspect of our growing understanding of Miocene hippopotamines is that the material attributed to Archaeopotamus is known only from the northeastern parts of the AfroArabian landmass (Kenya and Abu Dhabi). Whether these species actually formed a clade within Hippopotaminae or not, they are morphologically poor candidates for the late Miocene expansion of Hippopotamidae to southern Asia. The Siwalik forms, and notably Hex. sivalensis (Falconer and Cautley 1836), have derived crania and relatively short, deep and robust symphyses that are much more similar to the morphology observed in Hex. garyam from central Africa (Boisserie et al. 2005a). This and the fact that $A$. qeshta is the most archaic representative of the latest Miocene hippopotamines known suggest that, for hippopotamids, the Arabian Peninsula was not a pathway for dispersal toward southern Asia at this time period.

Finally, relative to their ecology, species of the Hippopotamine Event are distinct from earlier hippopotamids in being very abundant and in incorporating a greater proportion of $\mathrm{C}_{4}$ plants (presumably grasses) in their diet. Hippopotamids are abundant in the Baynunah Formation, comprising almost $20 \%$ of all collected large herbivore specimens (including equids, bovids, 
giraffids, suids, and proboscideans, see Bibi et al. this volume-a), a figure that compares with the relative frequency of hippopotamids in the Nawata Formation at Lothagam and in the Anthracotheriid Unit at Toros-Ménalla. At these latter two sites, hippopotamines are also the most abundant mammalian species. In the Baynunah Formation, A. qeshta is the fourth mostabundant mammalian species, following Hipparion abudhabiense, Stegotetrabelodon emiratus, and Abudhabia baynunensis.

The consumption of grasses, accounting for most of the $\mathrm{C}_{4}$ plants in tropical areas, is an important element of the Hippopotamine Event to the point that coevolution was suggested between hippopotamines and grass communities (Boisserie et al. 2011; Boisserie and Merceron 2011). Notably, Archaeopotamus harvardi and Hex. garyam had diets in which $\mathrm{C}_{4}$ plants occupied a significant to predominant proportion (Boisserie et al. 2005b; Cerling et al. 2003; Harris et al. 2008). The stable isotopic content of Baynunah hippopotamid (Kingston, 1999; Uno and Bibi, this volume) tooth enamel indicates a diet dominated by $\mathrm{C}_{4}$ plants, while $\delta^{18} \mathrm{O}$ values are among the lowest obtained for the whole fauna and support an interpretation of semi-aquatic habits (Bocherens et al. 1996; Cerling et al. 2003; Clementz and Koch 2001). These isotopic ecological features of the Baynunah hippopotamids therefore do not depart from those observed in other late Miocene hippopotamines, corroborating the scenario proposed for the Hippopotamine Event (Boisserie et al. 2011; Boisserie and Merceron 2011).

\section{Acknowledgments}

We would like to thank the following institutions for providing access to studied materials: Abu Dhabi Tourism and Culture Authority (ADTCA); Al Ain National Museum; Authority for Research and Conservation of Cultural Heritage, Addis Ababa; Centre National de la Recherche 
pour le Développement, N’Djaména; Kenyan National Museums, Nairobi; Natural History Museum, London. Special thanks to the staff of the ADTCA and to Pip Brewer and Spyridoula Pappa at the NHM. This study was performed with the support of SPLASH, research program ANR-15-CE32-0010-01 of the Agence National pour la Recherche. We finally thank three anonymous reviewers for helping to improve the manuscript.

\section{References}

Aguirre, E. (1963). Hippopotamus crusafonti n. sp. del Plioceno inferior de Arenas del Rey (Granada). Notas y Comunicaciones del Instituto Geologico y Minero de Espana, 69, $215-230$.

Alloing-Séguier, L., Lihoreau, F., Boisserie, J.-R., Charruault, A. L., Orliac, M., \& Tabuce, R. (2014). Enamel microstructure evolution in anthracotheres (Mammalia, Cetartiodactyla) and new insights on hippopotamoid phylogeny. Zoological Journal of the Linnean Society, 171, 668-695.

Arnason, U., Gullberg, A., Solweig, G., Ursing, B., \& Janke, A. (2000). The mitochondrial genome of the sperm whale and a new molecular reference for estimating eutherian divergence rate. Journal of Molecular Evolution, 50, 569-578.

Bengston, P. (1988). Open nomenclature. Palaeontology, 31(1), 223-227.

Bibi, F., Shabel, A. B., Kraatz, B. P., \& Stidham, T. A. (2006). New fossil ratite (Aves:

Palaeognathae) eggshell discoveries from the late Miocene Baynunah Formation of the United Arab Emirates, Arabian Peninsula. Palaeontologia Electronica, 9(1), 1-13.

Bibi, F., Hill, A., Beech, M., \& Yasin, W. (2013). Late Miocene fossils from the Baynunah Formation, United Arab Emirates: Summary of a decade of new work. In X. Wang, L. J. 
Flynn, \& M. Fortelius (Eds.), Fossil Mammals of Asia: Neogene Biostratigraphy and Chronology (pp. 583-594). New York: Columbia Univ. Press.

Bibi, F., Kaya, F., Varela, S. (this volume-a). Paleoecology and Paleobiogeography of the Baynunah Fauna. In F. Bibi, B. Kraatz, M. Beech, \& A. Hill (eds.) Sands of Time: Late Miocene Fossils from the Baynunah Formation, U.A.E. (pp. xxx). Cham: Springer.

Bibi, F., Beech, M., Hill., A, \& Kraatz, B. (this volume-b). Fossil Localities of the Baynunah Formation. In F. Bibi, B. Kraatz, M. Beech, \& A. Hill (eds.) Sands of Time: Late Miocene Fossils from the Baynunah Formation, U.A.E. (pp. xxx). Cham: Springer.

Bocherens, H., Koch, P. L., Mariotti, A., Geraads, D., \& Jaeger, J.-J. (1996). Isotopic biogeochemistry $\left({ }^{13} \mathrm{C},{ }^{18} \mathrm{O}\right)$ of mammalian enamel from African Pleistocene hominid sites. Palaïos, 11, 306-318.

Boisserie, J.-R. (2002). Nouveaux Hippopotamidae du Mio-Pliocène du Tchad et d'Éthiopie : implications phylogénétiques et paléoenvironnementales. Ph.D. dissertation, University of Poitiers.

Boisserie, J.-R. (2005). The phylogeny and taxonomy of Hippopotamidae (Mammalia: Artiodactyla): a review based on morphology and cladistic analysis. Zoological Journal of the Linnean Society, 143, 1-26.

Boisserie, J.-R., Brunet, M., Andossa, L., \& Vignaud, P. (2003). Hippopotamids from the Djurab Pliocene faunas, Chad, Central Africa. Journal of African Earth Sciences, 36, 15-27.

Boisserie, J.-R., Fisher, R. E., Lihoreau, F., \& Weston, E. M. (2011). Evolving between land and water: key questions on the emergence and history of the Hippopotamidae (Hippopotamoidea, Cetancodonta, Cetartiodactyla). Biological Reviews, 86, 601-625.

Boisserie, J.-R., \& Haile-Selassie, Y. (2009). Hippopotamidae. In Y. Haile-Selassie, \& G. WoldeGabriel (Eds.), Ardipithecus kadabba. Late Miocene Evidence from the Middle 
Awash, Ethiopia (pp. 273-287, Vol. The Middle Awash Series). Berkeley: University of California Press.

Boisserie, J.-R., Kiarie, C., Lihoreau, F., \& Nengo, I. (2017b). Middle Miocene Kenyapotamus (Cetartiodactyla, Hippopotamidae) from Napudet, Turkana Basin, Kenya. Journal of Vertebrate Paleontology 37(1), e12720552.

Boisserie, J.-R., Lihoreau, F., Orliac, M., Fisher, R. E., Weston, E. M., \& Ducrocq, S. (2010). Morphology and phylogenetic relationships of the earliest known hippopotamids (Cetartiodactyla, Hippopotamidae, Kenyapotaminae). Zoological Journal of the Linnean Society, 158, 325-366.

Boisserie, J.-R., Likius, A., Vignaud, P., \& Brunet, M. (2005a). A new late Miocene hippopotamid from Toros-Ménalla, Chad. Journal of Vertebrate Paleontology, 25(3), $665-673$.

Boisserie, J.-R., \& Merceron, G. (2011). Correlating the success of Hippopotaminae with the $\mathrm{C}_{4}$ grass expansion in Africa: relationship and diet of early Pliocene hippopotamids from Langebaanweg, South Africa. Palaeogeography, Palaeoclimatology, Palaeoecology, 308, $350-361$.

Boisserie, J.-R., Schuster, M., Beech, M. J., Hill, A., \& Bibi, F. (2017a) A new species of hippopotamine (Cetartiodactyla, Hippopotamidae) from the late Miocene Baynunah Formation, Abu Dhabi, United Arab Emirates. Palaeovertebrata, 41(1), e2.

Boisserie, J.-R., Suwa, S., Asfaw, B., Lihoreau, F., Bernor, R. L., Katoh, S., \& Beyene, Y. (2017c) Basal hippopotamines from the upper Miocene of Chorora, Ethiopia. Journal of Vertebrate Paleontology 37(3), e1297718.

Boisserie, J.-R., Zazzo, A., Merceron, G., Blondel, C., Vignaud, P., Likius, A., et al. (2005b). Diets of modern and late Miocene hippopotamids: evidence from carbon isotope 
composition and micro-wear of tooth enamel. Palaeogeography, Palaeoclimatology, Palaeoecology, 221, 153-174.

Cerling, T. E., Harris, J. M., \& Leakey, M. G. (2003). Isotope paleoecology of the Nawata and Nachukui Formations at Lothagam, Turkana Basin, Kenya. In M. G. Leakey, \& J. M. Harris (Eds.), Lothagam. The dawn of humanity in eastern Africa (pp. 605-624). New York: Columbia University Press.

Clementz, M. T., \& Koch, P. L. (2001). Differentiating aquatic mammal habitat and foraging ecology with stable isotopes in tooth enamel. Oecologia, 129, 461-472.

Coryndon, S. C. (1977). The taxonomy and nomenclature of the Hippopotamidae (Mammalia, Artiodactyla) and a description of two new fossil species. Proceedings of the Koninklijke Nederlandse Akademie van Wetenschappen, 80(2), 61-88.

Ditchfield, P., Hicks, J., Plummer, T., Bishop, L. C., \& Potts, R. (1999). Current research on the Late Pliocene and Pleistocene deposits north of Homa Mountain, southwestern Kenya. Journal of Human Evolution, 36, 123-150.

Falconer, H., \& Cautley, P. T. (1836). Note on the fossil hippopotamus of the Siwalik Hills. Asiatic Research Calcutta, 19(3), 39-53.

Gaziry, A. W. (1987). Hexaprotodon sahabiensis (Artiodactyla, Mammalia): a new hippopotamus from Libya. In N. T. Boaz, A. El-Arnauti, A. W. Gaziry, J. d. Heinzelin, \& D. Dechant Boaz (Eds.), Neogene paleontology and geology of Sahabi (pp. 303-315). New York: Alan R. Liss, Inc.

Gentry, A. W. (1999). A fossil hippopotamus from the Emirate of Abu Dhabi, United Arab Emirates. In P. J. Whybrow, \& A. Hill (Eds.), Fossil Vertebrates of Arabia (pp. 271-289). New Haven: Yale University Press. 
Gentry, A. W., \& Hooker, J. J. (1988). The phylogeny of the Artiodactyla. In M. J. Benton (Ed.), The phylogeny and classification of the Tetrapods, Volume 2 : Mammals (Vol. 35B, pp. 235-272, Systematics Association Special Volume). Oxford: Clarendon Press.

Gray, J. E. (1821). On the natural arrangement of vertebrose animals. London Medical Repository, 15, 296-310.

Harris, J. M., Cerling, T. E., Leakey, M. G., \& Passey, B. H. (2008). Stable isotope ecology of fossil hippopotamids from the Lake Turkana Basin of East Africa. Journal of Zoology, $275,323-331$.

Harrison, T. (1997). The anatomy, paleobiology, and phylogenetic relationships of the Hippopotamidae (Mammalia, Artiodactyla) from the Manonga Valley, Tanzania. In T. Harrison (Ed.), Neogene Paleontology of the Manonga Valley, Tanzania (pp. 137-190, Topics in Geobiology). New York: Plenum Press.

Hill, A., 1999. Late Miocene sub-Saharan African vertebrates, and their relation to the Baynunah faune, Emirate of Abu Dhabi, United Arab Emirates. In P. J. Whybrow, \& A. Hill (Eds.), Fossil Vertebrates of Arabia (pp. 420-429). New Haven: Yale University Press.

Katoh, S., Beyene, Y., Itaya, T., Hyodo, H., Hyodo, M., Yagi, K., et al. (2016). New geological and palaeontological age constraint for the gorilla-human lineage split. Nature, 530, 215218.

Kingston, J. D. (1999). Isotopes and environments of the Baynunah Formation, Emirate of Abu Dhabi, United Arab Emirates. In P. J. Whybrow, \& A. Hill (Eds.), Fossil Vertebrates of Arabia (pp. 354-372). New Haven: Yale University Press.

Lacomba, J. I., Morales, J., Robles, F., Santisteban, C., \& Alberdi, M. T. (1986). Sedimentologia y paleontologia del yacimiento finimioceno de La Portera (Valencia). Estudios Geológicos, 42, 167-180. 
Lihoreau, F., Boisserie, J.-R., Manthi, F. K., \& Ducrocq, S. (2015). Hippos stem from the longest sequence of terrestrial cetartiodactyl evolution in Africa. Nature Communications, $6(6264), 1-8$

Martínez, J.-N., \& Sudre, J. (1995). The astragalus of Paleogene artiodactyls: comparative morphology, variability and prediction of body mass. Lethaia, 28, 197-209.

Montgelard, C., Catzeflis, F. M., \& Douzery, E. (1997). Phylogenetic relationships of artiodactyls and cetaceans as deduced from the comparison of cytochrome $\mathrm{b}$ and $12 \mathrm{~s}$ rRNA mitochondrial sequences. Molecular Biology and Evolution, 14(5), 550-559.

Morton, S. G. (1849). Additional information on a new living species of Hippopotamus. Journal of the Academy of Natural Sciences of Philadelphia, 2(1), 231-239.

Orliac, M., Boisserie, J.-R., MacLatchy, L., \& Lihoreau, F. (2010). Early Miocene hippopotamids (Cetartiodactyla) constrain the phylogenetic and spatiotemporal settings of hippopotamid origin. Proceedings of the National Academy of Sciences of the United States of America, 107(26), 11871-11876.

Pavlakis, P. (2008). Rediscovered hippopotamid remains from As Sahabi. In N. T. Boaz, A. ElArnauti, P. P. Pavlakis, \& M. J. Salem (Eds.), Circum-Mediterranean geology and biotic evolution during the Neogene period: the perspective from Libya (Vol. Special Issue 5, pp. 179-187). Benghazi: University of Garyounis G. S. P. L. A. J.

Peppe, D. J., Evans, D. A. D., Beech, M., Hill, A., Bibi, F. (this volume). Magnetostratigraphy of the Baynunah Formation. In F. Bibi, B. Kraatz, M. Beech, \& A. Hill (eds.) Sands of Time: Late Miocene Fossils from the Baynunah Formation, U.A.E. (pp. xxx). Cham: Springer.

Pickford, M. (1983). On the origins of Hippopotamidae together with descriptions of two species, a new genus and a new subfamily from the Miocene of Kenya. Géobios, 16(2), 193-217. 
Suwa, G., Beyene, Y., Nakaya, H., Bernor, R. L., Boisserie, J.-R., Bibi, F., et al. (2015). Newly discovered cercopithecid, equid and other mammalian fossils from the Chorora Formation, Ethiopia. Anthropological Science, 123(1), 19-39.

Swofford, D. L. (2002). PAUP*. Phylogenetic Analysis Using Parsimony (*and other methods). Version 4. Sinauer Associates, Sunderland, Massachusetts.

Tsubamoto, T., Kunimatsu, Y., Nakaya, H., Sakai, T., Sayenoshi, M., Mbua, E., et al. (2016). New specimens of a primitive hippopotamus, Kenyapotamus coryndonae, from the upper Miocene Nakali Formation, Kenya. Journal of the Geological Society of Japan, 121(4), 153-159.

Uno, K. \& Bibi, F. (this volume). Stable isotope paleoecology of the Baynunah Formation. In F. Bibi, B. Kraatz, M. Beech, \& A. Hill (eds.) Sands of Time: Late Miocene Fossils from the Baynunah Formation, U.A.E. (pp. xxx). Cham: Springer.

Weston, E.M. (1997). A biometrical analysis of evolutionnary change within the Hippopotamidae. Ph.D. dissertation, Cambridge University.

Weston, E. M. (2000). A new species of hippopotamus Hexaprotodon lothagamensis (Mammalia : Hippopotamidae) from the late Miocene of Kenya. Journal of Vertebrate Paleontology, 20(1), 177-185

Weston, E. M. (2003). Fossil Hippopotamidae from Lothagam. In M. G. Leakey, \& J. M. Harris (Eds.), Lothagam. The dawn of humanity in eastern Africa (pp. 441-483). New York: Columbia University Press.

Whybrow, P. J., \& Hill, A. (1999). Fossil vertebrates of Arabia. New Haven: Yale University Press.

\section{Tables}


Table 15.1 Measurements (min.-max. in mm; mean; N) for mandibles of Archaeopotamus qeshta (in italics) compared to those of other hippopotamids

\begin{tabular}{|c|c|c|c|c|c|c|}
\hline & M1 & M2 & M3 & M4 & M5 & M6 \\
\hline AUH 457 & $\sim 355$ & $\sim 192$ & 117 & 52 & $\sim 96$ & 97 \\
\hline M49464 & $\sim 356$ & $\sim 165$ & 113 & 42 & 87 & $\sim 88$ \\
\hline AUH 481 & & 165 & $\sim 87$ & & $\sim 82$ & \\
\hline $\mathrm{KT}$ & & 104 & 47 & & 53 & \\
\hline $\mathrm{AL}$ & $\sim 302$ & $\sim 139$ & 101 & 44 & 92 & 80 \\
\hline \multirow{2}{*}{$\mathrm{AH}$} & $356-402$ & 183-211; & 152-187; & 40-63; & 81-124; & 99-124; \\
\hline & $380.8 ; 3$ & $191.8 ; 4$ & $168.8 ; 3$ & $48.9 ; 7$ & $102.0 ; 4$ & $108.4 ; 6$ \\
\hline AR & 328 & 155 & 126 & & & \\
\hline \multirow{2}{*}{$\mathrm{HG}$} & $375-410$ & 126-197; & 123-188; & 51-70; & 104-127; & 103-126; \\
\hline & $389.7 ; 3$ & $159.3 ; 9$ & $156.4 ; 10$ & $59.7 ; 9$ & $116.7 ; 7$ & $116.3 ; 15$ \\
\hline HS & & 127 & 112 & & 83 & \\
\hline
\end{tabular}

Taxa: AL Archaeopotamus lothagamensis from Lothagam, AH Archaeopotamus harvardi from Lothagam, AR Archaeopotamus aff. harvardi from Rawi, HG Hexaprotodon garyam from Toros- 
Ménalla, HS Hexaprotodon? sahabiensis from Sahabi (data from Pavlakis 2008), KT Kenyapotamus ternani from Napudet (data from Boisserie et al. 2017-a).

Measurements: $M 1$ length from mid-point between right and left $\mathrm{I} /{ }_{1}$ to distal $\mathrm{M} / 3, M 2$ symphysis length (maximal length from mid-point between right and left $\mathrm{I} /{ }_{1}$ and nuchal symphysis), $M 3$ width between right and left canines, $M 4$ corpus mediolateral thickness below $\mathrm{M} / 1, M 5$ corpus height at mesial $\mathrm{P} / 2, M 6$ corpus height at mesial $\mathrm{M} / 3$.

Table 15.2 Proportions of $\mathrm{I}^{2} /$ (min.-max.; mean; N) and interincisive ratios (min.-max.; mean; N) in Archaeopotamus qeshta (in italics) compared to those of other hippopotamids.

\begin{tabular}{|c|c|c|c|c|c|}
\hline & $\mathrm{I}^{2} / \mathrm{S}$ & $\mathrm{I}^{2} /{ }^{1}$ & $\mathrm{I}^{3} / 1$ & $\mathrm{I}_{2} / \mathrm{I}_{1}$ & $\mathrm{I}_{3} / 1$ \\
\hline$A Q$ & $\begin{array}{l}70.5-76.7 ; \\
73.42 ; 3\end{array}$ & 98.2 & 62.9 & $\begin{array}{c}\text { 108.4-140.6; } \\
\text { 126.29; } 3\end{array}$ & $\begin{array}{l}90.9-123.5 ; \\
107.20 ; 2\end{array}$ \\
\hline $\mathrm{KT}$ & & & & 146.2 & 103.2 \\
\hline $\mathrm{AL}$ & & & & 153.3 & 205.5 \\
\hline $\mathrm{AH}$ & 91.0 & 109.3 & 87.7 & $\begin{array}{c}\text { 62.7-79.6; 71.14; } \\
2\end{array}$ & 69.1 \\
\hline AR & & & & 43.2 & 71.3 \\
\hline \multirow[t]{2}{*}{$\mathrm{HG}$} & 90.0-123.5; & 81.1-126,5; & 89.4-111.7; & 54.4-90.8; 69.69; & 64.2-100.1; 83.4; \\
\hline & $110.12 ; 7$ & $104.04 ; 4$ & $99.88 ; 3$ & 10 & 10 \\
\hline
\end{tabular}




\begin{tabular}{llll}
\hline $\mathrm{WM}$ & 99.6 & 107.2 & 81.3
\end{tabular}

Taxa: AQ Archaeopotamus qeshta, AL Archaeopotamus lothagamensis from Lothagam, AH Archaeopotamus harvardi from Lothagam, AR Archaeopotamus aff. harvardi from Rawi, $H G$ Hexaprotodon garyam from Toros-Ménalla, HS Hexaprotodon? sahabiensis from Sahabi (data from Gaziry 1987), KT Kenyapotamus ternani from Napudet (data from Boisserie et al. 2017-a), WM Hippopotaminae indet. from Adu-Asa Formation.

Measurements: $I^{2} / S$ : shape ratio of the $\mathrm{I}^{2} /$ cross-section, $100 \times(\mathrm{LL} / \mathrm{MD})$ in which LL is the linguolabial diameter and MD the mesiodistal diameter. $I^{2 / 1}$ ratio $100 \times\left(\mathrm{I}^{2} / \mathrm{MD} \times \mathrm{I}^{2} / \mathrm{LL}\right) /\left(\mathrm{I}^{1} /\right.$ $\left.\mathrm{MD} \times \mathrm{I}^{1 / \mathrm{LL}}\right), I^{3} / 1$ ratio $100 \times\left(\mathrm{I}^{3} / \mathrm{MD} \times \mathrm{I}^{3} / \mathrm{LL}\right) /\left(\mathrm{I}^{1} / \mathrm{MD} \times \mathrm{I}^{1} / \mathrm{LL}\right), I_{2} /{ }_{1}$ ratio $100 \times\left(\mathrm{I} /{ }_{2} \mathrm{MD} \times \mathrm{I} / 2\right.$ $\mathrm{LL}) /\left(\mathrm{I} /{ }_{1} \mathrm{MD} \times \mathrm{I} /{ }_{1} \mathrm{LL}\right), I_{3} /{ }_{1}$ ratio $100 \times\left(\mathrm{I} /{ }_{3} \mathrm{MD} \times \mathrm{I} /{ }_{3} \mathrm{LL}\right) /\left(\mathrm{I} /{ }_{1} \mathrm{MD} \times \mathrm{I} /{ }_{1} \mathrm{LL}\right)$. These values are calculated from measurements summarized in Tables 15.3 and 15.4.

Table 15.3 Measurements (min.-max. in mm; mean; N) for rostral upper dentition of Archaeopotamus qeshta (in italics) compared to those of other hippopotamids.

\begin{tabular}{|c|c|c|c|c|c|c|}
\hline & \multicolumn{2}{|c|}{$\mathrm{I}^{1 /}$} & \multicolumn{2}{|c|}{$\mathrm{I}^{2} /$} & \multicolumn{2}{|c|}{$\mathrm{I}^{3} /$} \\
\hline & MD & LL & MD & LL & MD & LL \\
\hline$A Q$ & 18.3 & 17.6 & $\begin{array}{c}\text { 20.8-21.7; } \\
21.17 ; 3\end{array}$ & $\begin{array}{c}15.2-16.1 \\
15.53 ; 3\end{array}$ & 15.0 & 13.5 \\
\hline $\mathrm{AH}$ & 24.0 & 22.6 & 25.5 & 23.2 & 20.9 & 22.7 \\
\hline $\mathrm{HG}$ & 13.9-21.9; & 13.2-23.3; & 18.3-22.6; & 18.8-25.3; & 12.1-19.3; & 13.5-22.4; \\
\hline
\end{tabular}




\section{$18.42 ; 3$ \\ $19.31 ; 4$ \\ $20.55 ; 6$ \\ $22.80 ; 6$ \\ $15.93 ; 6$ \\ $19.26 ; 5$}

Taxa: AQ Archaeopotamus qeshta, AH Archaeopotamus harvardi from Lothagam, $H G$ Hexaprotodon garyam from Toros-Ménalla.

Measurements: $M D$ mesiodistal diameter, $L L$ labiolingual diameter, $M A X$ maximum diameter, MIN minimum diameter.

Table 15.4 Measurements (min.-max. in mm; mean; N) for rostral lower dentition of Archaeopotamus qeshta (in italics) compared to those of other hippopotamids.

\begin{tabular}{|c|c|c|c|c|c|c|c|c|}
\hline & \multicolumn{2}{|c|}{$\mathrm{I} / 1$} & \multicolumn{2}{|c|}{$\mathrm{I} / 2$} & \multicolumn{2}{|c|}{$\mathrm{I} / 3$} & \multicolumn{2}{|c|}{$\mathrm{C} /{ }_{1}$} \\
\hline & MD & LL & $\mathrm{MD}$ & LL & MD & LL & MAX & MIN \\
\hline \multirow{2}{*}{$A Q$} & 10.4-14.8; & & & & 11.8-16.1; & \multirow{2}{*}{14.9} & 42.6-44.6; & 24.0-27.9; \\
\hline & $12.60 ; 2$ & $17.40 ; 2$ & $16.70 ; 2$ & $15.45 ; 2$ & $13.95 ; 2$ & & $43.60 ; 2$ & $25.95 ; 2$ \\
\hline \multirow{2}{*}{$\mathrm{KT}$} & \multirow{2}{*}{7.4} & \multirow{2}{*}{9.9} & \multirow{2}{*}{9.0} & \multirow{2}{*}{11.9} & \multirow{2}{*}{6.3} & \multirow{2}{*}{12.0} & & \\
\hline & & & & & & & $26.25 ; 2$ & $16.30 ; 2$ \\
\hline $\mathrm{AL}$ & 10.7 & 11.1 & 15.6 & 11.7 & 18.4 & 13.3 & 32.1 & 17.8 \\
\hline \multirow{2}{*}{$\mathrm{AH}$} & 23.1-26.7; & 28.5-23.2; & 17.4-25.2; & 19.3-24.0; & \multirow{2}{*}{19.0} & 19.5-21.7; & 34.6-58.2; & 23.1-35.7; \\
\hline & $24.90 ; 2$ & $25.85 ; 2$ & $21.30 ; 2$ & $21.65 ; 2$ & & $20.60 ; 2$ & $45.03 ; 6$ & $27.51 ; 7$ \\
\hline AR & 23.8 & 20.0 & 12.3 & 16.7 & 17.4 & 19.5 & 45.0 & 27.2 \\
\hline \multirow{2}{*}{$\mathrm{HG}$} & 21.3-31.7 & 18.5-37.4; & 16.1-32.0; & 18.8-30.4; & 18.4-31.8; & 19.3-33.0; & 39.7-68.5; & 25.7-39.7; \\
\hline & $27.23 ; 9$ & $28.74 ; 9$ & $22.62 ; 9$ & 24.04; 9 & $26.36 ; 8$ & $26.36 ; 9$ & 55.23: 9 & $34.21 ; 9$ \\
\hline
\end{tabular}




$\begin{array}{lllllllll}\text { HS } & 23.8 & 20.0 & 12.3 & 16.7 & 17.4 & 19.5 & 45.0 & 27.2\end{array}$

Taxa: AQ Archaeopotamus qeshta, AL Archaeopotamus lothagamensis from Lothagam, AH Archaeopotamus harvardi from Lothagam, AR Archaeopotamus aff. harvardi from Rawi, $H G$ Hexaprotodon garyam from Toros-Ménalla, HS Hexaprotodon? sahabiensis from Sahabi (data from Pavlakis 2008), KT Kenyapotamus ternani from Napudet (data from Boisserie et al. 2017a).

Measurements: $M D$ mesiodistal diameter, $L L$ labiolingual diameter, $M A X$ maximum diameter, MIN minimum diameter.

Table 15.5 Measurements (min.-max. in mm; mean; N) for upper third premolar of Archaeopotamus qeshta (in italics) compared to those of other hippopotamids.

\begin{tabular}{ccc}
\hline & \multicolumn{2}{c}{$\mathrm{P}^{3} /$} \\
& $\mathrm{L}$ & $\mathrm{W}$ \\
\hline$A Q$ & 37.8 & $\sim 30.6$ \\
$\mathrm{KE}$ & $25.0-29.4 ;$ & $19.7-20.3 ;$ \\
& $27.20 ; 2$ & $20.00 ; 2$ \\
$\mathrm{AH}$ & $35.4-48.2 ;$ & $27.4-35.1 ;$ \\
& $40.35 ; 10$ & $31.70 ; 9$ \\
$\mathrm{HG}$ & & \\
& $35.6-47.0 ;$ & $28.2-43.0 ;$
\end{tabular}

$34.15 ; 31$ 
$41.22 ; 31$

HS $\quad 36.0 \quad 26.0$

$\begin{array}{lll}\text { WM } & 38.6 & 26.2\end{array}$

Taxa: AQ Archaeopotamus qeshta, AH Archaeopotamus harvardi from Lothagam, $H G$ Hexaprotodon garyam from Toros-Ménalla, HS Hexaprotodon? sahabiensis from Sahabi (data from Gaziry 1987), KE middle and late Miocene Kenyapotamus from Kenya, WM Hippopotaminae indet. from Adu-Asa Formation.

Measurements: $L$ mesiodistal length, $W$ maximal width.

Table 15.6 Measurements (min.-max. in mm; mean; N) for lower premolars of Archaeopotamus qeshta (in italics) compared to those of other hippopotamids.

\begin{tabular}{|c|c|c|c|c|c|c|c|c|}
\hline & \multicolumn{2}{|c|}{$\mathrm{P} / 1$} & \multicolumn{2}{|c|}{$\mathrm{P} / 2$} & \multicolumn{2}{|c|}{$\mathrm{P} / 3$} & \multicolumn{2}{|c|}{$\mathrm{P} / 4$} \\
\hline & $\mathrm{L}$ & W & $\mathrm{L}$ & W & $\mathrm{L}$ & W & $\mathrm{L}$ & W \\
\hline \multirow{2}{*}{$A Q$} & 17.3-18.7; & 11.4-13.4; & 29.2-40.2 & 18.2-19.7; & 35.7-39.1; & 19.6-23.1; & 33.9-34.5; & 22.4-23.8; \\
\hline & $17.55 ; 2$ & $12.40 ; 2$ & $34.70 ; 2$ & $18.95 ; 2$ & $37.40 ; 2$ & $21.35 ; 2$ & $34.20 ; 2$ & $23.10 ; 2$ \\
\hline \multirow{2}{*}{$\mathrm{KE}$} & & & 18.8 & 11.0 & & & & \\
\hline & & & & & $27.85 ; 2$ & $16.30 ; 2$ & $25.90 ; 2$ & $18.55 ; 2$ \\
\hline \multirow[t]{2}{*}{$\mathrm{AL}$} & & & & & & & 30.7-33.6; & 20.5-23.8; \\
\hline & & & & & & & $32.15 ; 2$ & $22.15 ; 2$ \\
\hline
\end{tabular}


$\mathrm{AH}$

$31.3-41.0 ; \quad 21.4-24.7 ; \quad 36.5-45.1 ; \quad 22.5-26.6 ; \quad 36.4-41.6 ; \quad 24.9-30.6$ $36.27 ; 6 \quad 22.85 ; 5 \quad 40.04 ; 6 \quad 24.62 ; 6 \quad 38.66 ; 8 \quad 27.41 ; 8$

AR

36.9

22.3

$\mathrm{HG}$

$16.3-33.1 ; \quad 11.2-40.7 ; \quad 29.8-47.1 ; \quad 19.0-27.6 ; \quad 31.7-48.0 ; \quad 18.0-32.9 ; \quad 33.4-43.1 ; \quad 21.7-32.5 ;$

$24.7 ; 2 \quad 25.95 ; 2 \quad 35.99 ; 17 \quad 22.12 ; 17 \quad 39.42 ; 20 \quad 24.17 ; 19 \quad 39.10 ; 19 \quad 27.81 ; 18$

HS

WM

$17.4-18.5 ; \quad 13.3-14.5 ;$

$37.5-40.1 ; \quad 23.1-26.8 ; \quad 38.1-43.9 ; \quad 25.8-31.0$

$17.95 ; 2 \quad 13.90 ; 2$

$38.60 ; 3 \quad 25.07 ; 3 \quad 41.43 ; 3 \quad 28.73 ; 3$

Taxa: AQ Archaeopotamus qeshta, AL Archaeopotamus lothagamensis from Lothagam, AH Archaeopotamus harvardi from Lothagam, AR Archaeopotamus aff. harvardi from Rawi, $H G$ Hexaprotodon garyam from Toros-Ménalla, HS Hexaprotodon? sahabiensis from Sahabi (data from Gaziry 1987), KE middle and late Miocene Kenyapotamus from Kenya and Tunisia, WM Hippopotaminae indet. from Adu-Asa Formation.

Measurements: $L$ mesiodistal length, $W$ maximal width.

Table 15.7 Measurements (min.-max. in mm; mean; N) for upper molars of Archaeopotamus qeshta (in italics) compared to those of other hippopotamids.

\begin{tabular}{|c|c|c|c|c|c|c|}
\hline & \multicolumn{2}{|c|}{$\mathrm{M}^{2} /$} & \multicolumn{4}{|c|}{$\mathrm{M}^{3} /$} \\
\hline & $\mathrm{L}$ & W & $\mathrm{L}$ & W & $\mathrm{h}$ & $\mathrm{H}$ \\
\hline$A Q$ & 46.0 & 44.6 & 42.6 & 44.4 & 34.0 & 76.6 \\
\hline
\end{tabular}




\begin{tabular}{|c|c|c|c|c|c|c|}
\hline KE & $\begin{array}{c}22.6-29.0 \\
25.92 ; 4\end{array}$ & $\begin{array}{c}24.6-25.7 \\
26.05 ; 2\end{array}$ & $\begin{array}{c}20.0-29.7 \\
24.85 ; 2\end{array}$ & $\begin{array}{c}23.0-29.4 \\
25.63 ; 3\end{array}$ & 18.8 & 66.6 \\
\hline $\mathrm{AH}$ & $\begin{array}{l}37.2-50.0 \\
44.58 ; 16\end{array}$ & $\begin{array}{l}39.7-55.6 \\
45.99 ; 16\end{array}$ & $\begin{array}{l}44.0-51.7 \\
47.17 ; 13\end{array}$ & $\begin{array}{l}41.4-56.2 \\
46.48 ; 13\end{array}$ & 32.1 & 76.6 \\
\hline HG & $\begin{array}{l}42.4-54.3 \\
48.37 ; 35\end{array}$ & $\begin{array}{l}41.2-53.5 \\
47.38 ; 30\end{array}$ & $\begin{array}{l}37.8-57.4 \\
47.74 ; 49\end{array}$ & $\begin{array}{l}40.8-52.2 \\
46.54 ; 48\end{array}$ & $\begin{array}{c}34.6-40.0 \\
36.41 ; 8\end{array}$ & $\begin{array}{c}\text { 73.7-81.4; } \\
78.49 ; 8\end{array}$ \\
\hline HS & & & 39.0 & 42.0 & & \\
\hline WM & $\begin{array}{c}45.4-46.2 \\
45.80 ; 2\end{array}$ & $\begin{array}{c}44.4-45.5 \\
44.95 ; 2\end{array}$ & $\begin{array}{c}43.4-49.2 \\
46.68 ; 4\end{array}$ & $\begin{array}{l}39.1-45.9 \\
42.77 ; 4\end{array}$ & 36.4 & 107.2 \\
\hline
\end{tabular}

Taxa: AQ Archaeopotamus qeshta, AH Archaeopotamus harvardi from Lothagam, $H G$ Hexaprotodon garyam from Toros-Ménalla, HS Hexaprotodon? sahabiensis from Sahabi (data from Gaziry 1987), KE middle and late Miocene Kenyapotamus from Kenya and Tunisia, $W M$ Hippopotaminae indet. from Adu-Asa Formation.

Measurements: $L$ mesiodistal length, $W$ maximal width, $h$ paracone height from cervix to apex, $H$ hypsodonty index $100 \times \mathrm{h} / \mathrm{W}$.

Table 15.8 Measurements (min.-max. in mm; mean; N) for lower molars of Archaeopotamus qeshta (in italics) compared to those of other hippopotamids. 


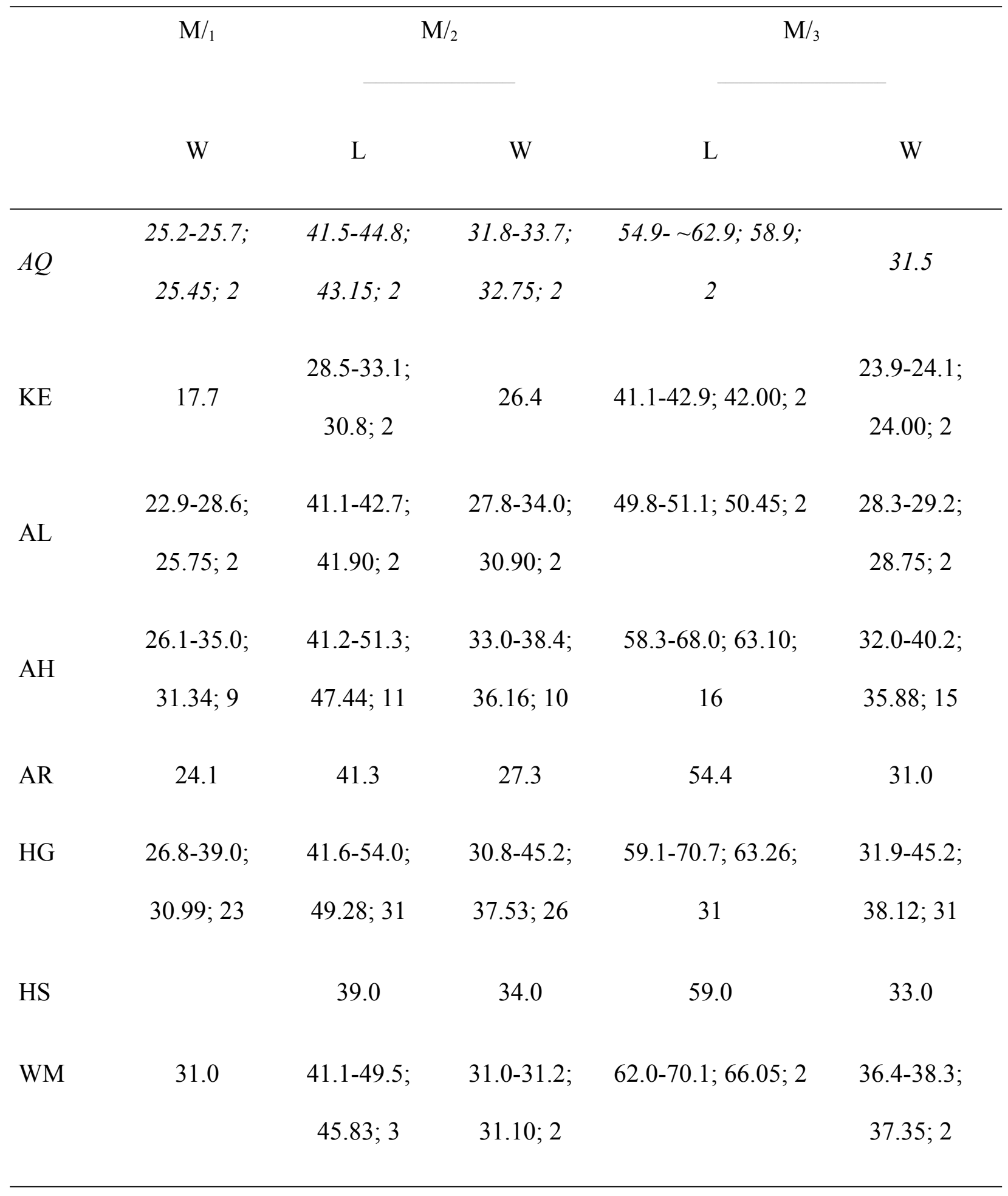

Taxa: AQ Archaeopotamus qeshta, AL Archaeopotamus lothagamensis from Lothagam, $A H$ Archaeopotamus harvardi from Lothagam, AR Archaeopotamus aff. harvardi from Rawi, $H G$ 
Hexaprotodon garyam from Toros-Ménalla, HS Hexaprotodon? sahabiensis from Sahabi (data from Gaziry 1987), KE middle and late Miocene Kenyapotamus from Kenya and Tunisia, WM Hippopotaminae indet. from Adu-Asa Formation.

Measurements: $L$ mesiodistal length, $W$ maximal width.

Table 15.9 Measurements (min.-max. in mm; mean; N) and proportions of lower dental rows (min.-max. in mm; mean; N) in Archaeopotamus qeshta (in italics) compared to those of other hippopotamids.

\begin{tabular}{lccc}
\hline & $\mathrm{P}$ & $\mathrm{M}$ & $100 \times(\mathrm{P} / \mathrm{M})$ \\
\hline AUH 457 & 126 & 127 & 99.2 \\
M49464 & 131 & $\sim 142$ & 92.3 \\
KE & $72-104 ; 87.9 ; 2$ & $95-103 ; 99.0 ; 2$ & 101.0 \\
AL & 105 & 123 & 85.4 \\
AH & $104-130 ; 118.9 ; 7$ & $134-152 ; 144.9 ; 8$ & $70.2-90.2 ; 81.94 ; 5$ \\
AR & 118 & 134 & 88.1 \\
HG & $90-132 ; 116.4 ; 8$ & $133-163 ; 148.2 ; 13$ & $67.7-84.9 ; 74.9 ; 6$ \\
\hline
\end{tabular}

Taxa: AL Archaeopotamus lothagamensis from Lothagam, AH Archaeopotamus harvardi from Lothagam, AR Archaeopotamus aff. harvardi from Rawi, HG Hexaprotodon garyam from TorosMénalla, HS Hexaprotodon? sahabiensis from Sahabi (data from Pavlakis 2008), KE middle and late Miocene Kenyapotamus from Kenya and Tunisia. 
Measurements: $P$ length from mesial $\mathrm{P} / 2$ to distal $\mathrm{P} / 4, M$ length from mesial $\mathrm{M} / 1$ to distal $\mathrm{M} / 3$.

Table 15.10 Measurements (min.-max. in mm; mean; N), proportion (min.-max.; mean; N), and estimated weight (min.-max. in kg; mean; N) for astragali in Baynunah hippopotamines (in italics) and other late Miocene hippopotamids.

\begin{tabular}{|c|c|c|c|c|}
\hline & $\mathrm{H}$ & $\mathrm{W}$ & $100 \times W / H$ & EM \\
\hline$B F$ & $77.7-90.7 ; 83.9 ; 3$ & $44.5-46.9 ; 46.0 ; 3$ & $55.9-57.3 ; 56.6 ; 2$ & $555-655 ; 605 ; 2$ \\
\hline $\mathrm{KC}$ & $58.0-61.5 ; 59.8 ; 2$ & $33.2-36.0 ; 2$ & $54.0-62.1 ; 58.0 ; 2$ & $254-263 ; 259 ; 2$ \\
\hline LTH & $80.2-117.9 ; 97.6 ; 14$ & $\begin{array}{c}\text { 49.0-71.0; 58.1; } \\
14\end{array}$ & $51.8-65.5 ; 59.6 ; 14$ & $671-2,0556 ; 1,202 ; 14$ \\
\hline $\mathrm{TM}$ & $100.2-121.8 ; 109.5 ; 10$ & $\begin{array}{c}56.2-70.4 ; 63.0 \\
10\end{array}$ & $55.7-59.7 ; 57.7 ; 10$ & $1,230-2,132 ; 1,612 ; 8$ \\
\hline WM & $101.3-123.9 ; 111.9 ; 9$ & $61.6-73.9 ; 66.8 ; 8$ & $55.9-63.0 ; 59.8 ; 8$ & $1,397-2,279 ; 1,753 ; 8$ \\
\hline
\end{tabular}

Taxa: BF Baynunah Formation, Abu Dhabi, KC Kenyapotamus cf. coryndonae from the Nakali Formation and Ngeringerowa (data for Ngeringerowa from Pickford 1983, data for Nakali from Tsubamoto et al. 2016), LTH Nawata Formation at Lothagam (data for $A$. harvardi from Weston 2003), TM Toros-Ménalla in the Djourab, WM Adu-Asa Formation in Middle Awash Measurements: $H$ maximal proximodistal length, $W$ proximal trochlea transversal width, $E M$ estimated mass using Martinez \& Sudre (1995)'s allometry equation $3.16 \times(\mathrm{H} \times \mathrm{W})^{1.482}$. 
Table 15.11 Proportions (min.-max.; mean; N) for metapodials in Baynunah hippopotamines (in italics) and other late Miocene hippopotamines.

\begin{tabular}{|c|c|c|c|c|c|}
\hline & Mc III & Mc IV & $\mathrm{Mc} \mathrm{V}$ & Mt II & Mt III \\
\hline$B F$ & 23.1 & 24.4 & 30.2 & 22.9 & $\begin{array}{c}\text { 23.1-26.1; } \\
24.6 ; 2\end{array}$ \\
\hline LTL & & & 27.6 & & \\
\hline LTH & $\begin{array}{c}17.3-18.1 ; 17.8 ; \\
3\end{array}$ & $20.8-22.2 ; 21.5 ; 2$ & $25.7-28.0 ; 26.5 ; 3$ & $\begin{array}{c}17.0-24.3 ; \\
20.7 ; 2\end{array}$ & $\begin{array}{c}20.5-24.5 ; 22.5 \\
5\end{array}$ \\
\hline TM & $\begin{array}{c}21.9-29.9 ; 25.9 \\
2\end{array}$ & $22.8-25.1 ; 23.7 ; 5$ & 25.6 & & $\begin{array}{c}23.7-24.9 ; 24.5 ; \\
4\end{array}$ \\
\hline
\end{tabular}

Taxa: BF Baynunah Formation in Abu Dhabi, LTL Nawata Formation at Lothagam (data for $A$. lothagamensis from Weston 2003), LTH Nawata Formation at Lothagam (data for A. harvardi from Weston 2003), TM Toros-Ménalla in the Djourab.

Measurements: $M c$ metacarpal, $M t$ metatarsal. These values are calculated from measurements summarized in Tables 15.12 and 15.13 as following: $100 \times \mathrm{L} / \mathrm{W}$.

Table 15.12 Measurements (min.-max. in mm; mean; N) for metacarpals in Baynunah hippopotamines (in italics) and other late Miocene hippopotamines.

Mc III
Mc V 


\begin{tabular}{|c|c|c|c|c|c|c|}
\hline & $\mathrm{L}$ & W & $\mathrm{L}$ & W & L & W \\
\hline$B F$ & $\begin{array}{l}\text { 140-142; } \\
40.9 ; 2\end{array}$ & 33 & 122 & 30 & 91 & 28 \\
\hline LTL & & & & & 76 & 21 \\
\hline LTH & $\begin{array}{l}177-185 \\
180.3 ; 3\end{array}$ & $\begin{array}{l}32-32 \\
32.0 ; 3\end{array}$ & $\begin{array}{l}154-162 \\
158.0 ; 2\end{array}$ & $\begin{array}{c}32-36 ; 34.0 \\
2\end{array}$ & $\begin{array}{l}101-125 \\
111.7 ; 3\end{array}$ & $\begin{array}{c}26-35 ; 29.7 \\
3\end{array}$ \\
\hline $\mathrm{TM}$ & $\begin{array}{l}154-187 \\
170.6 ; 2\end{array}$ & $\begin{array}{l}41-46 ; \\
43.6 ; 2\end{array}$ & $\begin{array}{l}145-158 \\
153.5 ; 5\end{array}$ & $\begin{array}{c}35-38 ; 36.4 \\
5\end{array}$ & 109.9 & 28.1 \\
\hline
\end{tabular}

Taxa: $B F$ Baynunah Formation in Abu Dhabi, LTL Nawata Formation at Lothagam (data for $A$. lothagamensis from Weston 2003), LTH Nawata Formation at Lothagam (data for A. harvardi from Weston 2003), TM Toros-Ménalla in the Djourab.

Measurements: $M c$ metacarpal, $L$ proximodistal length, $W$ mid-diaphysis transversal width.

Table 15.13 Measurements (min.-max. in $\mathrm{mm}$; mean; $\mathrm{N}$ ) for metatarsals in Baynunah hippopotamines (in italics) and other late Miocene hippopotamines.

\begin{tabular}{lcccc}
\hline \multicolumn{3}{c}{ Mt II } & & \multicolumn{2}{c}{ Mt III } \\
& L & W & L & W \\
\hline BF & 96 & 22 & $110-119 ; 114.5 ; 2$ & $28-29 ; 28.1 ; 2$ \\
& & & & \\
LTH & $106-111 ; 108.5 ; 2$ & $18-27 ; 22.5 ; 2$ & $134-166 ; 148.8 ; 5$ & $29-37 ; 33.4 ; 5$
\end{tabular}


Taxa: BF Baynunah Formation in Abu Dhabi, $L T H$ Nawata Formation at Lothagam (data for $A$. harvardi from Weston 2003), TM Toros-Ménalla in the Djourab.

Measurements: $M t$ metatarsal, $L$ proximodistal length, $W$ mid-diaphysis transversal width.

Table 15.14 Measurements (min.-max. in mm; mean; N) and proportion (min.-max.; mean; N) for proximal phalanges III or IV in Baynunah hippopotamines (in italics) and other late Miocene hippopotamines.

\begin{tabular}{lccc}
\hline & $\mathrm{L}$ & $\mathrm{W}$ & $100 \times \mathrm{W} / \mathrm{L}$ \\
\hline$B F$ & $58.6-64.5 ; 60.8 ; 3$ & $34.2-38.5 ; 36.3 ; 3$ & $56.0-62.9 ; 59.7 ; 3$ \\
& & & \\
TM & $70.6-73.7 ; 72.5 ; 3$ & $40.2-42.0 ; 41.3 ; 3$ & $56.5-57.4 ; 56.9 ; 3$ \\
& & & \\
WM & $66.3-79.4 ; 73.2 ; 6$ & $42.5-51.6 ; 46.7 ; 6$ & $61.4-65.0 ; 63.8 ; 6$ \\
\hline
\end{tabular}

Taxa: BF Baynunah Formation in Abu Dhabi, TM Toros-Ménalla in the Djourab, WM Adu-Asa Formation in Middle Awash.

Measurements: $L$ proximodistal length, $W$ mid-diaphysis transversal width. 


\section{Figure Captions}

Fig. 15.1 Adult mandibles of Archaeopotamus qeshta from the Baynunah Formation, Abu Dhabi, United Arab Emirates. (a-d) NHM M49464, holotype mandible of $A$. qeshta. (a) dorsal view. (b) dentition: top left, occlusal view of right $\mathrm{P} / 4$; top right, lingual view of right $\mathrm{P} / 4$; middle, occlusal view of left $\mathrm{M} / 2$; bottom left, occlusal view of left $\mathrm{M} / 3$; bottom right, occlusal of right $\mathrm{M} /{ }_{3}$. (c) rostrodorsal view. (d) left lateral view. (e-f) AUH 457. (e) dorsal view. (f) left lateral view.

Fig. 15.2 AUH 481, juvenile mandible of Archaeopotamus qeshta from the Baynunah Formation, Abu Dhabi, United Arab Emirates. (a) dorsal view. (b) rostrodorsal view. (c) right lateral view.

Fig. 15.3 Measurements and proportions of Archaeopotamus qeshta compared with those of other hippopotamids. (a) plot of mandibular symphysis proportions: M2 maximal length from mid-point between right and left $\mathrm{I} /{ }_{1}$ and nuchal symphysis, $M 3$ width between right and left canines, $M 5$ corpus height at mesial $\mathrm{P} / 2$. (b) plot of $\mathrm{M} /{ }_{3}$ dimensions: $L$ mesiodistal length, $W$ mesial width.

Fig. 15.4 Cross-sections of mandibular symphyses attributed to Archaeopotamus qeshta compared with those of other hippopotamids. All sections are direct observations, except Hexaprotodon? sahabiensis (Pavlakis 2008: fig. 3). 
Fig. 15.5 Dentition of Archaeopotamus qeshta from the Baynunah Formation, Abu Dhabi, United Arab Emirates. (a) AUH 1731, left $\mathrm{I}^{2} /$ in mesial view on left and in lingual view on right. (b) NHM M49465, right $\mathrm{P}^{3} /$ in occlusal view on left and in labial view on right. (c) AUH 262, ?right $\mathrm{P}^{4} /$ in occlusal view on top and in distal view on bottom. (d) AUH 664, left $\mathrm{P} / 1$ in lingual view on top and in distal view on bottom. (e) AUH 1532 (right $\mathrm{M}^{2} /$ in occlusal view on left and in labial view on right). (f) $\mathrm{AUH} 36$, right $\mathrm{M}^{3}$ / in occlusal view on left and in lingual view on right.

Fig. 15.6 Consensus of 33 most parsimonious trees (1091 steps, consistency index $=0.293$, retention index $=0.636$ ). (a) clade Hippopotamoidea, (b) clade (Hippopotamidae, Bothriodontinae), (c) clade Hippopotamidae, (d) clade Hippopotaminae. Abbreviations: $A$. Archaeopotamus, Akx. Anthracokeryx, Ant., Anthracotherium, Bot. Bothriogenys, Bra. Brachyodus, Elo. Elomeryx, Ken. Kenyapotamus, Lib. Libycosaurus, Mer. Merycopotamus. 
Fig. 15.1

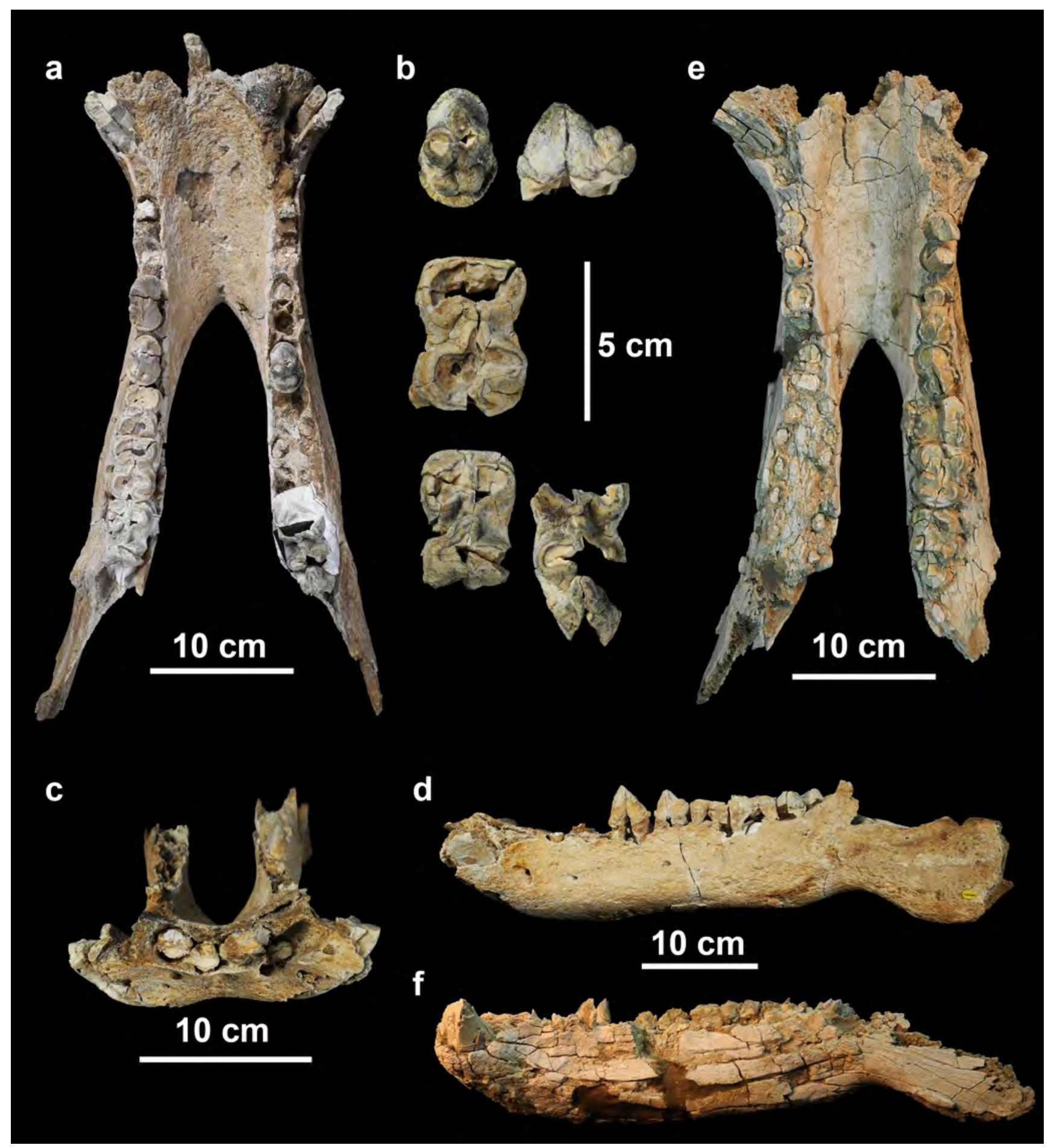


Fig. 15.2

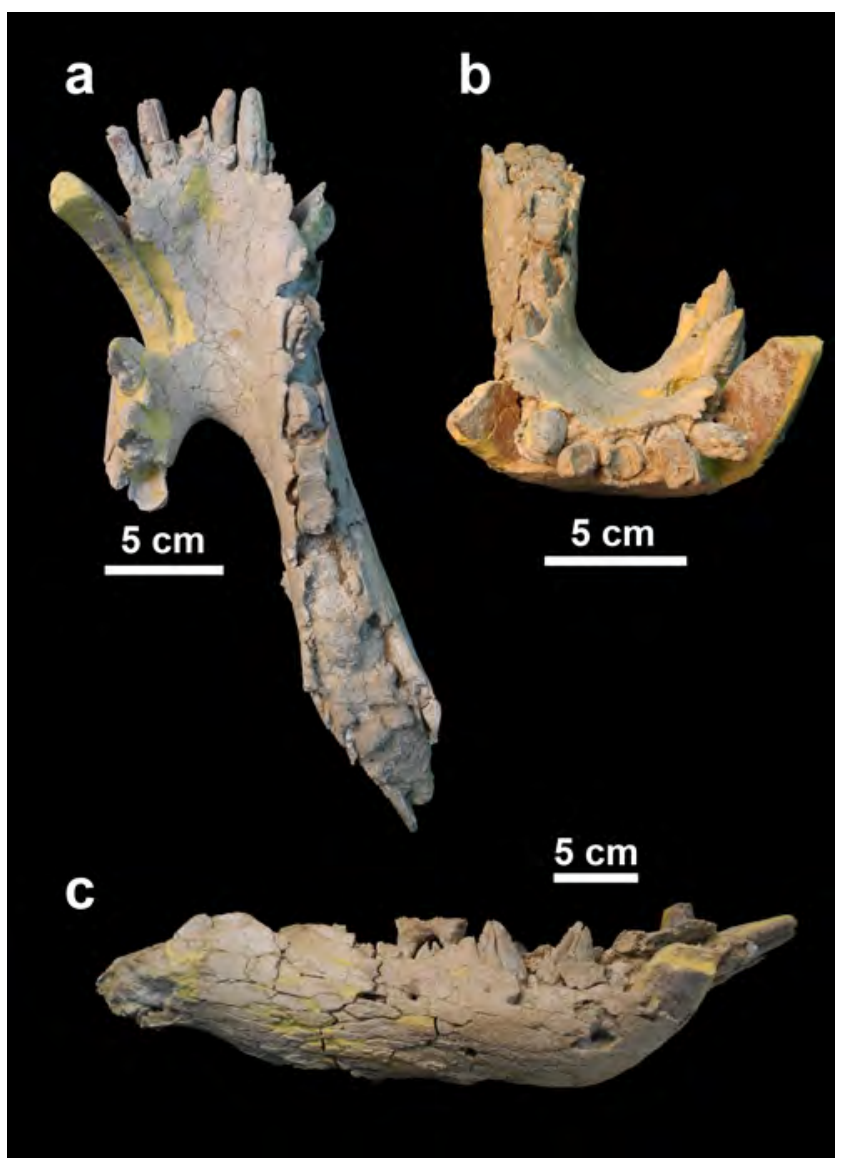


Fig. 15.3
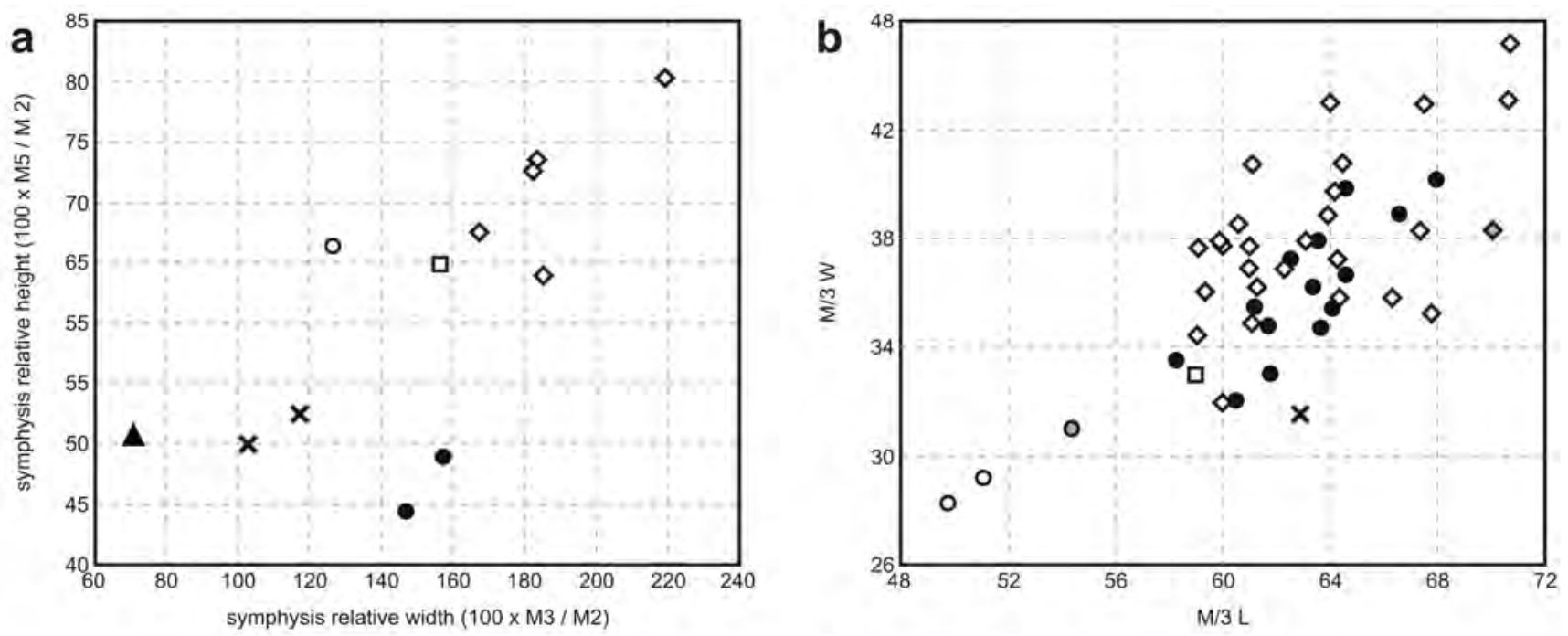

X Archaeopotamus qeshta from Baynunah

$\diamond$ Hexaprotodon garyam

- Archaeopotamus lothagamensis

ㅁ Hexaprotodon sahabiensis

- Archaeopotamus harvardi

$\diamond$ Hippopotamidae indet. from WM

- Archaeopotamus aff. harvardi from Rawi

A Kenyapotamus ternani from Napudet 
Fig. 15.4

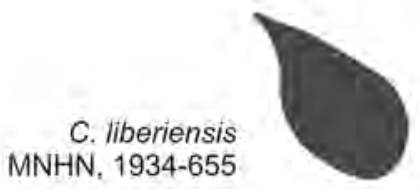

\section{Archaeopotamus qeshta from Baynunah}
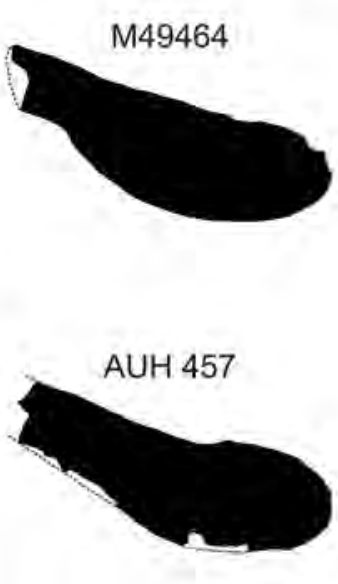

Hex. garyam CNRD, TM 43-97-002

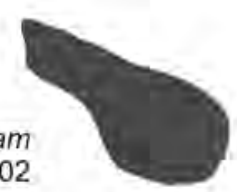

Hex. garyam CNRD, TM 337-01-001

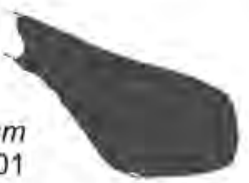

Hex. ? sahabiensis
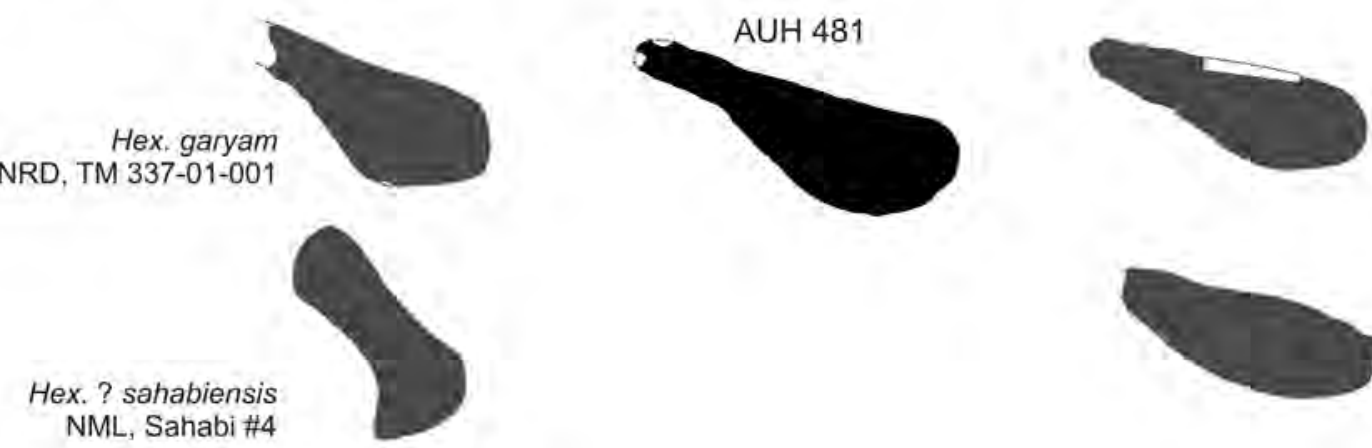

A. aff harvard NHM, M15939 (Rawi)

NML, Sahabi \#4

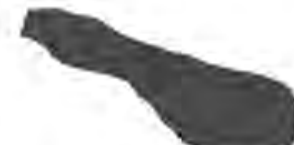

A. harvardi

KNM, KNM-LT 23888

A. harvardi

KNM, KNM-LT 23896

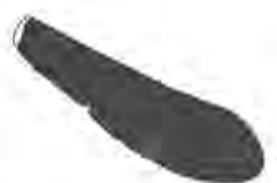

A. lothagamensis

KNM, KNM-LT 23839

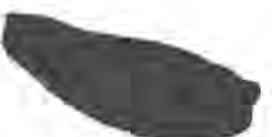

K. ternani

TBI, KNM-NP 64505 
Fig. 15.5

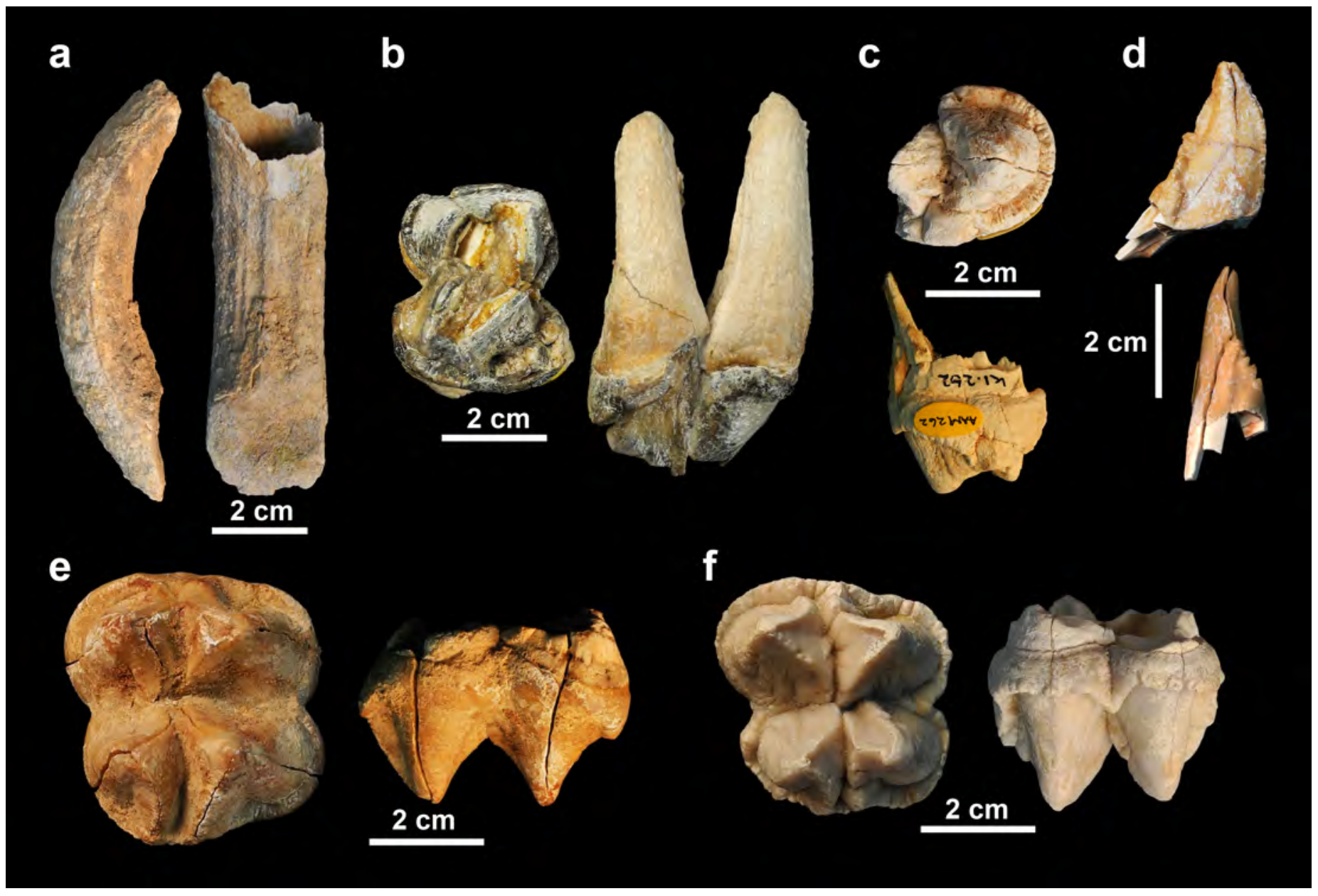


Fig. 15.6

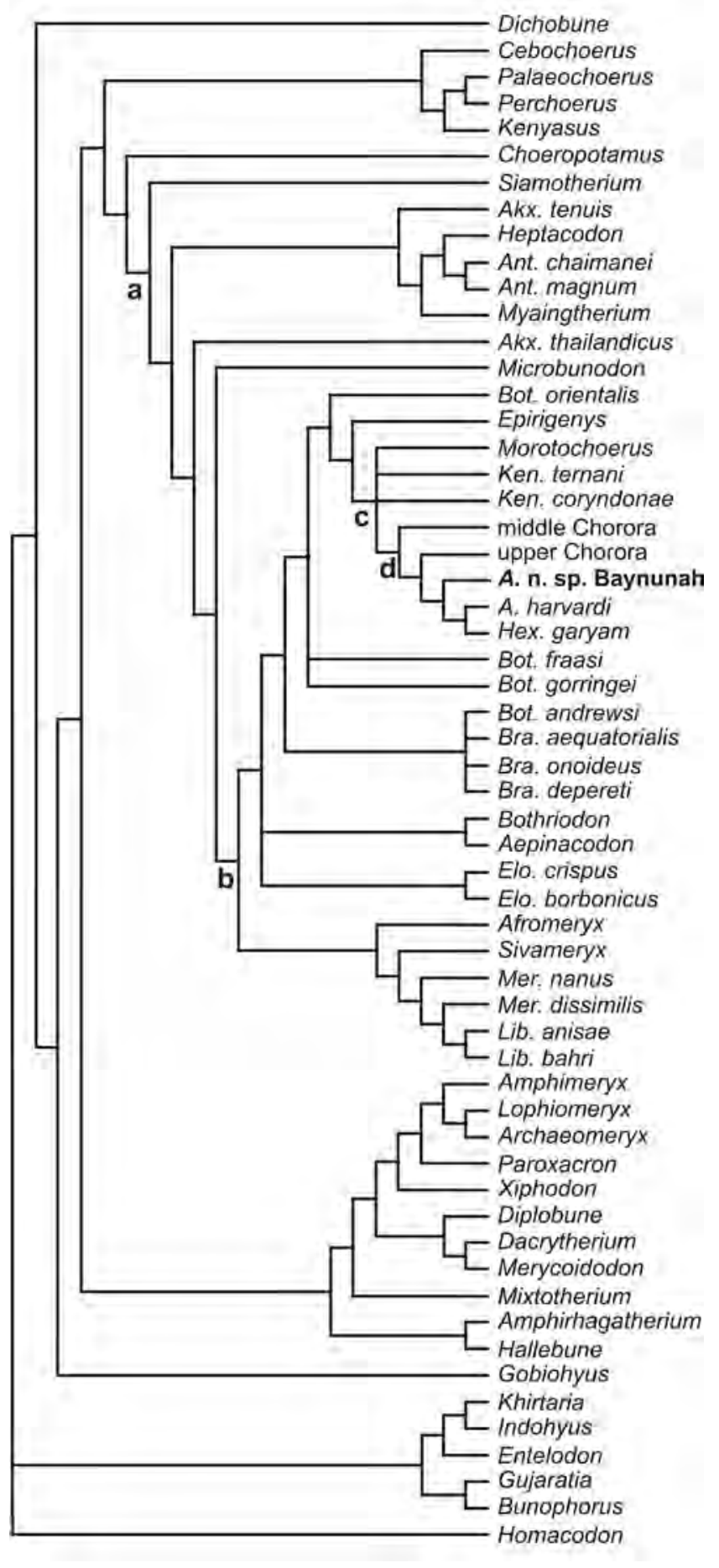

